Article

\title{
Short-Term Assessment of Nitrous Oxide and Methane Emissions on a Crop Yield Basis in Response to Different Organic Amendment Types in Sichuan Basin
}

\author{
Dayo George Oladipo ${ }^{1,2}$, Kai Wei ${ }^{1, *}$, Lei Hu ${ }^{1,2}$, Ayodeji Medaiyese ${ }^{3}$, Hamidou Bah ${ }^{4}$, \\ Lanre Anthony Gbadegesin ${ }^{1,2}$ and Bo Zhu ${ }^{1, *}$ \\ 1 Key Laboratory of Mountain Surface Processes and Ecological Regulation, \\ Institute of Mountain Hazards and Environment, Chinese Academy of Sciences, Chengdu 610041, China; \\ dayo@imde.ac.cn (D.G.O.); hulei@imde.ac.cn (L.H.); lanre2020@imde.ac.cn (L.A.G.) \\ 2 University of Chinese Academy of Sciences, Beijing 100049, China \\ 3 School of Science and the Environment, Grenfell Campus, Memorial University of Newfoundland, \\ Corner Brook, NL A2H 5G4, Canada; aomedaiyese@grenfell.mun.ca \\ 4 Institut Supérieur Agronomique et Vétérinaire de Faranah (ISAV/F), Faranah 131, Guinea; \\ bahamidou2004@imde.ac.cn \\ * Correspondence: weikai@imde.ac.cn (K.W.); bzhu@imde.ac.cn (B.Z.)
}

check for updates

Citation: Oladipo, D.G.; Wei, K.; Hu, L.; Medaiyese, A.; Bah, H.;

Gbadegesin, L.A.; Zhu, B. Short-Term Assessment of Nitrous Oxide and Methane Emissions on a Crop Yield Basis in Response to Different Organic Amendment Types in Sichuan Basin. Atmosphere 2021, 12, 1104. https://doi.org/10.3390/ atmos12091104

Academic Editor: Xiaopeng Gao

Received: 2 July 2021

Accepted: 24 August 2021

Published: 26 August 2021

Publisher's Note: MDPI stays neutral with regard to jurisdictional claims in published maps and institutional affiliations.

Copyright: (c) 2021 by the authors. Licensee MDPI, Basel, Switzerland. This article is an open access article distributed under the terms and conditions of the Creative Commons Attribution (CC BY) license (https:// creativecommons.org/licenses/by/ $4.0 /)$.
Abstract: Agriculture's goal to meet the needs of the increasing world population while reducing the environmental impacts of nitrogen $(\mathrm{N})$ fertilizer use without compromising output has proven to be a challenge. Manure and composts have displayed the potential to increase soil fertility. However, their potential effects on nitrous oxide $\left(\mathrm{N}_{2} \mathrm{O}\right)$ and methane $\left(\mathrm{CH}_{4}\right)$ emissions have not been properly understood. Using field-scaled lysimeter experiments, we conducted a one-year study to investigate $\mathrm{N}_{2} \mathrm{O}$ and $\mathrm{CH}_{4}$ emissions, their combined global warming potential (GWP: $\mathrm{N}_{2} \mathrm{O}+\mathrm{CH}_{4}$ ) and yieldscaled GWP in a wheat-maize system. One control and six different organic fertilizer treatments receiving different types but equal amounts of $\mathrm{N}$ fertilization were used: synthetic $\mathrm{N}$ fertilizer (NPK), $30 \%$ pig manure $+70 \%$ synthetic $\mathrm{N}$ fertilizer (PM30), $50 \%$ pig manure $+50 \%$ synthetic $\mathrm{N}$ fertilizer (PM50), 70\% pig manure + 30\% synthetic N fertilizer (PM70), 100\% pig manure (PM100), 50\% cow manure-crop residue compost $+50 \%$ synthetic $\mathrm{N}$ fertilizer (CMRC), and $50 \%$ pig manure-crop residue compost $+50 \%$ synthetic $\mathrm{N}$ fertilizer (PMRC). Seasonal cumulative $\mathrm{N}_{2} \mathrm{O}$ emissions ranged from $0.39 \mathrm{~kg} \mathrm{~N} \mathrm{ha}^{-1}$ for the PMRC treatment to $0.93 \mathrm{~kg} \mathrm{~N} \mathrm{ha}^{-1}$ for the NPK treatment. Similar $\mathrm{CH}_{4}$ uptakes were recorded across all treatments, with values ranging from $-0.68 \mathrm{~kg} \mathrm{C} \mathrm{ha}^{-1}$ for the PM50 treatment to $-0.52 \mathrm{~kg} \mathrm{C}^{-1}$ for the PM30 treatment. Compared to the NPK treatment, all the organic-amended treatments significantly decreased $\mathrm{N}_{2} \mathrm{O}$ emission by $32-58 \%$ and GWP by $30-61 \%$. However, among the manure-amended treatments, only treatments that consisted of inorganic $\mathrm{N}$ with lower or equal proportions of organic manure $\mathrm{N}$ treatments were found to reduce $\mathrm{N}_{2} \mathrm{O}$ emissions while maintaining crop yields at high levels. Moreover, of all the organic-amended treatments, PMRC had the lowest yield-scaled GWP, owing to its ability to significantly reduce $\mathrm{N}_{2} \mathrm{O}$ emissions while maintaining high crop yields, highlighting it as the most suitable organic fertilization treatment in Sichuan basin wheat-maize systems.

Keywords: greenhouse gases; nitrous oxide emissions; methane emissions; yield-scaled GWP; manure; compost; best management practices; organic amendment

\section{Introduction}

Greenhouse gas (GHG) emissions from agricultural ecosystems continue to remain a major source of concern due to agriculture's net contribution to global radiative forcing. The contribution of agriculture to atmospheric GHG emissions accounts for about one-third of the total emissions when direct energy use, fertilizer and pesticide manufacturing, indirect livestock emissions, the use of machinery and equipment, land degradation, harvest 
and residue management, and land-use change are taken into consideration [1]. Nowadays, agricultural GHG emissions are continually on the increase due to the intensification of conventional agricultural practices, which seek to meet the increasing demand for global food production to feed the teeming world population [2]. However, with proper management, greenhouse gas emissions associated with agriculture can be reduced significantly [3,4]. In order to overcome the triple issues of food sustainability, environmental degradation, and global warming, the application of organic amendment on farmlands could present the opportunity to reduce the intensive reliance on synthetic fertilizers, protect the environment, further improve crop yields, retain soil fertility, and ultimately mitigate GHG emissions [3,5].

China has a massive potential for mainstreaming organic amendment application to farmland [1]. The country produces over $600 \mathrm{Tg}$ of crop residues and has the capacity to generate more than $3.8 \mathrm{Tg}$ of nitrogen annually [6]. Similarly, China produces about $3.8 \mathrm{Tg}$ of manure annually, which has the potential of generating up to 262 billion RMB (40.5 billion USD) in yearly revenue and can satisfy its current nitrogen (N) demands by as much as $50 \%[7,8]$. China's massive potential for organic amendment application has necessitated a wide range of studies seeking to understand the agronomic and environmental impacts of organic amendments on agricultural soils [8-10]. For example, Zhou et al. (2013) have found out that organic amended soils could produce yields similar to that of the conventional $\mathrm{N}$ fertilizer treatments in Sichuan wheat-maize systems [5]. Yao et al. (2009) observed that applying organic amendments could decrease GHG emissions by up to $32 \%$ compared to conventional $\mathrm{N}$ fertilizers while showing the same, or even an increase in crop yields with respect to conventional $\mathrm{N}$ fertilizer treatments [11].

Nitrous oxide $\left(\mathrm{N}_{2} \mathrm{O}\right)$ and methane $\left(\mathrm{CH}_{4}\right)$ are important greenhouse gasses, most especially in agriculture, [12] as agriculture contributes about $60 \%$ and $47 \%$ to the overall anthropogenic emissions for $\mathrm{N}_{2} \mathrm{O}$ and $\mathrm{CH}_{4}$, respectively, primarily from soils and $\mathrm{N}$ inputs to soil systems [12]. An increasing number of studies are beginning to explore the dynamics of $\mathrm{N}_{2} \mathrm{O}$ and $\mathrm{CH}_{4}$ emissions and the processes that control them in fertilizer-amended soils. However, there remains a lot to be understood, most especially in organic-amended soils. $\mathrm{N}_{2} \mathrm{O}$ in agricultural soils is mainly produced through two microbial-mediated processes: nitrification and denitrification. Nitrification is the aerobic oxidation of ammonium $\left(\mathrm{NH}_{4}{ }^{+}\right)$ to nitrate $\left(\mathrm{NO}_{3}{ }^{-}\right)$via nitrite $\left(\mathrm{NO}_{2}{ }^{-}\right)$, with the production of nitric oxide $(\mathrm{NO})$ and $\mathrm{N}_{2} \mathrm{O}$ as by-products. Denitrification is a process (or a series of processes) that converts $\mathrm{NO}_{3}{ }^{-}$to nitrogen gas $\left(\mathrm{N}_{2}\right)$ through $\mathrm{NO}_{2}{ }^{-}$, with $\mathrm{NO}$ and $\mathrm{N}_{2} \mathrm{O}$ as intermediates [13]. Environmental factors such as soil temperature, moisture, aeration, available $\mathrm{C}$ and $\mathrm{N}$ contents could significantly impact the microbial processes that drive $\mathrm{N}_{2} \mathrm{O}$ production in agricultural systems [14]. Similarly, the magnitude and direction of $\mathrm{CH}_{4}$ emissions could also be dependent on these factors [5,15]. Studies have demonstrated that the choice of fertilizer could have a significant impact on these soil conditions and, consequently, on $\mathrm{N}_{2} \mathrm{O}$ and $\mathrm{CH}_{4}$ emissions in soil systems [11,12,15]. However, at present, there is a wide range of contrasting reports about the effects of soil organic amendment on $\mathrm{N}_{2} \mathrm{O}$ and $\mathrm{CH}_{4}$ emission. As for $\mathrm{N}_{2} \mathrm{O}$ emissions in agricultural ecosystems, some studies have observed that soils amended with organic manures tend to boost $\mathrm{N}_{2} \mathrm{O}$ emissions in the soil [16-18], while others have noted that the integration of organic amendments such as animal manure with high quantities of labile carbon (C) into the soil could result in a decrease in $\mathrm{N}_{2} \mathrm{O}$ emissions, owing to the drop in $\mathrm{N}_{2} \mathrm{O}: \mathrm{N}_{2}$ ratio during the denitrification process [19-21]. This is usually apparent in high-moisture environments, particularly under high precipitation or irrigation conditions [19-21]. As for $\mathrm{CH}_{4}$ fluxes, some reports have identified the role of $\mathrm{N}$ fertilization on soil's $\mathrm{CH}_{4}$ uptake capacity [22]. Aronson and Helliker (2010) and Hütsch (2001) noted that $\mathrm{N}$ application could inhibit soil's $\mathrm{CH}_{4}$ uptake capacity [23,24], while Bodelier et al. (2004), on the other hand, pointed out in their study that the $\mathrm{CH}_{4}$ uptake capacity of soils could be increased with $\mathrm{N}$ fertilizer inputs [25]. Different from the above results, Zhou et al. (2013) observed no significant difference in the $\mathrm{CH}_{4}$ uptake capacities of soils receiving the same amount but different types of $\mathrm{N}$ fertilizer [5]. However, it is unclear 
how differential increases in manure $\mathrm{N}$ ratio would influence $\mathrm{N}_{2} \mathrm{O}$ and $\mathrm{CH}_{4}$ emissions in upland soils if the same amount of total $\mathrm{N}$ in a fertilization combination is maintained. Conducting such research could help to properly understand how GHGs fluxes respond to differential increases in the ratio of manure $\mathrm{N}$ in fertilization treatments receiving the same quantity of $\mathrm{N}$ fertilizer, which could also guide in understanding the threshold above or below which organic amendment application would have a negative impact on crop productivity and atmospheric GHG emissions in Sichuan basin agroecosystems.

Additionally, some important research in agricultural waste management has studied the use of composts [26,27], digestates [28,29], biochars [30], and the direct application of organic wastes such as raw crop residues and manures to the soil [31,32]. While there have been extensive research studies on agricultural waste utilization, particularly in terms of how the incorporation of crop residues and organic manure contributes to air and water pollution, to date there is still a sparsity of studies on how compost utilization affects $\mathrm{N}_{2} \mathrm{O}$ and $\mathrm{CH}_{4}$ emissions, particularly in the Sichuan basin region of southwest China, which is an intensive agrarian region, responsible for up to $10 \%$ of China's food production [33]. A location-specific investigation is essential because $\mathrm{N}_{2} \mathrm{O}$ and $\mathrm{CH}_{4}$ fluxes of different systems in one region could vary from another region due to differences in environmental factors and soil management practices [34]. Therefore, it is pertinent to understand how these GHG emissions respond to different organic amendments in a given cropping system.

The goals of the present article are to: (1) quantify the amount of $\mathrm{N}_{2} \mathrm{O}$ and $\mathrm{CH}_{4}$ emissions associated with different types of organic amendments in the Sichuan basin region of southwest China, (2) identify the drivers controlling GHG emissions in organicamended wheat-maize purple soil systems in the Sichuan basin region of southwest China, and (3) assess the impact of $\mathrm{N}$ fertilizer types, and differential increase in the ratio of organic manure $\mathrm{N}$ on $\mathrm{N}_{2} \mathrm{O}$ and $\mathrm{CH}_{4}$ emissions on a crop-yield basis in the wheat-maize systems and to identify best management practices (BMPs) for $\mathrm{N}$ fertilization in the Sichuan basin region of southwest China. For this purpose, we utilized the static chamber-gas chromatography (GC) technique to account for the greenhouse gas fluxes associated with each fertilization treatment. Then we evaluated the yield-scaled global warming potential (GWP) associated with the $\mathrm{N}_{2} \mathrm{O}$ and $\mathrm{CH}_{4}$ emissions of each treatment. This is an important metric for accounting for agronomic efficiency and determining the BMPs that would reduce agricultural greenhouse emissions whilst maintaining high crop grain yields for a given agricultural system.

\section{Materials and Methods}

\subsection{Experimental Site Description}

The experimental study was carried out between November 2019 and September 2020 at the Yanting Agroecological Station of Purple Soil, in Yanting Sichuan, China $\left(31^{\circ} 16^{\prime} \mathrm{N}\right.$, $105^{\circ} 28^{\prime} \mathrm{E}$, and $420 \mathrm{~m}$ altitude, Figure 1). The study area has a moderate subtropical monsoon climate with a mean annual temperature of $16.6^{\circ} \mathrm{C}$ and annual precipitation of $846.4 \mathrm{~mm}$. The soil used in this study was the Eutric Regosols (FAO Soil Taxonomy), also known as Pup-Orthic-Entisols (Chinese Soil Taxonomy) [33], which is native to the agroecosystem in the area. The soil has a clay loam texture, a $\mathrm{pH}\left(\mathrm{H}_{2} \mathrm{O}\right.$ : soil of 2.5:1 w/w) of 8.22 , a bulk density of $1.33 \mathrm{~kg} \mathrm{~m}^{-3}$, organic $\mathrm{C}$ content of $8.75 \mathrm{~g} \mathrm{~kg}^{-1}$ and a total $\mathrm{N}$ of $0.62 \mathrm{~g} \mathrm{~kg}^{-1}$ [35]. 


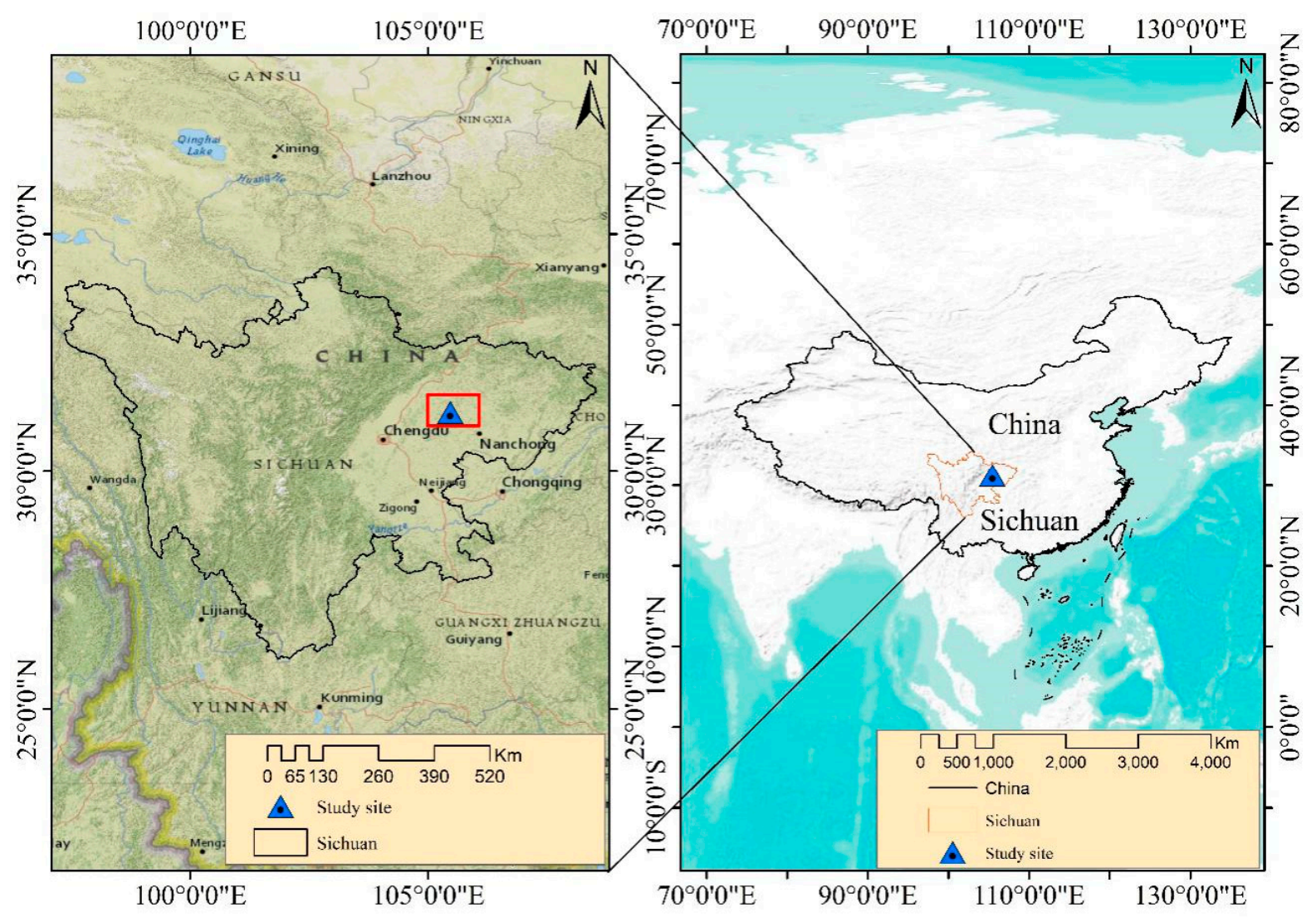

Figure 1. Map of the study area.

The experimental study site lies at the heart of the Sichuan Basin, an agrarian region with high agricultural potential. The region is suitable for wheat (Triticum aestivum L.), rice (Oryza sativa L.), maize (Zea mays L.), among other crops [5,9,35]. Most cropping systems around the zone are wheat-maize rotation-based, with wheat cultivation in the winter season and maize cultivation during summer around early June.

\subsection{Experimental Design}

The fertilization experiment was initiated in November 2019, and a winter wheatsummer maize cropping rotation was used. The experiment was laid out as a randomized complete block design consisting of seven treatments replicated four times. Each experimental plot was $1 \mathrm{~m}$ by $1 \mathrm{~m}$ in size. The winter wheat was sown at a plant density of $7,400,000$ plants per hectare, while the summer maize season was sown at a plant density of 50,000 plants per hectare, with a plant spacing of $0.3 \mathrm{~m}$.

A full synthetic fertilizer (NPK) was used as the control treatment, with all the fertilization treatments receiving the same amount but different types of $\mathrm{N}$ fertilization. For four of the treatments, pig manure was added in different proportions: $30 \%, 50 \%$, $70 \%$ and $100 \%$. Two different compost treatments were also applied. The composts were made by co-composting wheat straw and rapeseed residues with pig or cow manure, and were prepared according to the steps highlighted by Raza et al. (2020) [26]. N fertilization rate was kept constant across all the treatments at a rate of $280 \mathrm{~kg} \mathrm{~N} \mathrm{ha}^{-1} \mathrm{yr}^{-1}$, with $130 \mathrm{~kg} \mathrm{~N} \mathrm{ha}^{-1}$ being applied for the winter wheat season and $150 \mathrm{~kg} \mathrm{~N} \mathrm{ha}^{-1}$ for the summer maize season. The urea (46-0-0) was used as the chemical $\mathrm{N}$ fertilizer in our study.

Additionally, calcium superphosphate and potassium chloride were applied to each plot at the rate of $90 \mathrm{~kg} \mathrm{P}_{2} \mathrm{O}_{5} \mathrm{ha}^{-1}$ and $36 \mathrm{~kg} \mathrm{~K}_{2} \mathrm{O} \mathrm{ha}{ }^{-1}$, respectively. The fertilizers were added as basal fertilization at the beginning of each planting season. Planting and fertilization were undertaken on 7 November 2019 for the wheat season and on 5 June 2020 
for the maize season, while harvesting took place on 9 May 2020 for the wheat season and on 29 September 2020 for the maize season. A scheme of the $\mathrm{N}$ fertilization plan is highlighted in Table 1, and the total C, N, phosphorus (P) and potassium (K) contents of the organic amendments used are given in Table 2.

Table 1. Nitrogen fertilizer forms and application rates.

\begin{tabular}{|c|c|c|c|c|c|c|c|c|}
\hline \multirow[b]{2}{*}{ Treatment } & \multicolumn{4}{|c|}{ Winter Wheat Season } & \multicolumn{4}{|c|}{ Summer Maize Season } \\
\hline & $\begin{array}{c}\text { Urea } \\
\left(\mathrm{kg} \mathrm{N} \mathrm{ha}^{-1}\right)\end{array}$ & $\begin{array}{c}\text { Pig } \\
\text { Manure } \\
\left(\mathrm{kg} \mathrm{N} \mathrm{ha}^{-1}\right)\end{array}$ & $\begin{array}{c}\text { Compost } \\
\left(\mathrm{kg} N \mathrm{ha}^{-1}\right)\end{array}$ & $\begin{array}{c}\text { Total N } \\
\text { Applied } \\
\left(\mathrm{kg} \mathrm{N} \mathrm{ha}^{-1}\right)\end{array}$ & $\begin{array}{c}\text { Urea } \\
\left(\mathrm{kg} \mathrm{N} \mathrm{ha}^{-1}\right)\end{array}$ & $\begin{array}{c}\text { Pig } \\
\text { Manure } \\
\left(\mathrm{kg} \mathrm{N} \mathrm{ha}^{-1}\right)\end{array}$ & $\begin{array}{c}\text { Compost } \\
(\mathrm{kg} \mathrm{N} \mathrm{ha-1)}\end{array}$ & $\begin{array}{c}\text { Total N } \\
\text { Applied } \\
\left(\mathrm{kg} \mathrm{N} \mathrm{ha}{ }^{-1}\right)\end{array}$ \\
\hline NPK & 130 & 0 & 0 & 130 & 150 & 0 & 0 & 150 \\
\hline PM30 & 91 & 39 & 0 & 130 & 105 & 45 & 0 & 150 \\
\hline PM50 & 65 & 65 & 0 & 130 & 75 & 75 & 0 & 150 \\
\hline PM70 & 39 & 91 & 0 & 130 & 45 & 105 & 0 & 150 \\
\hline PM100 & 0 & 130 & 0 & 130 & 0 & 150 & 0 & 150 \\
\hline CMRC & 65 & 0 & $65^{1}$ & 130 & 75 & 0 & $75^{1}$ & 150 \\
\hline PMRC & 65 & 0 & $65^{2}$ & 130 & 75 & 0 & $75^{2}$ & 150 \\
\hline
\end{tabular}

Synthetic N fertilizer (NPK), 30\% pig manure $+70 \%$ synthetic $\mathrm{N}$ fertilizer (PM30), 50\% pig manure $+50 \%$ synthetic $\mathrm{N}$ fertilizer (PM50), $70 \%$ pig manure $+30 \%$ synthetic $\mathrm{N}$ fertilizer (PM70), 100\% pig manure (PM100), 50\% cow manure-crop residue compost $+50 \%$ synthetic $\mathrm{N}$ fertilizer (CMRC), and 50\% pig manure-crop residue compost $+50 \%$ synthetic $\mathrm{N}$ fertilizer (PMRC). ${ }^{1}$ Cow manure-crop residue compost,

${ }^{2}$ Pig manure-crop residue compost.

Table 2. Physicochemical properties of the organic amendments used.

\begin{tabular}{|c|c|c|c|c|c|}
\hline Organic Amendment Added & $\begin{array}{c}\text { Total N } \\
\text { Content }^{1}(\%)\end{array}$ & $\begin{array}{c}\text { Total C } \\
\text { Content }^{1}(\%)\end{array}$ & C:N Ratio & $\begin{array}{c}\text { Total P } \\
\text { Content }^{1}\left(\mathrm{~g} \mathrm{~kg}^{-1}\right)\end{array}$ & $\begin{array}{c}\text { Total K } \\
\text { Content }^{1}\left(\mathrm{~g} \mathrm{~kg}^{-1}\right)\end{array}$ \\
\hline Pig Manure & $2.2 \pm 0.1$ & $31.4 \pm 0.6$ & 14.1:1 & $5.7 \pm 0.4$ & $16.8 \pm 0.6$ \\
\hline Pig manure-crop residue compost & $2.0 \pm 0.1$ & $25.1 \pm 0.7$ & $12.5: 1$ & $7.7 \pm 0.3$ & $12.1 \pm 2.2$ \\
\hline Cow manure-crop residue compost & $1.9 \pm 0.0$ & $24.9 \pm 0.3$ & 13.1:1 & $3.4 \pm 0.3$ & $13.8 \pm 2.0$ \\
\hline
\end{tabular}

${ }^{1}$ Average of four replicates \pm standard error.

\subsection{Gas Sampling and Flux Measurement}

The soil greenhouse gas fluxes associated with each treatment were measured using the static chamber-GC method from November 2019 to September 2020 [36,37]. The manual chambers had two components: the base collar and the chamber cover, all of which were made of stainless steel. The base collars were inserted at the center of each field plot at a depth of $0.1 \mathrm{~m}$ and held in place for the entire measurement duration. The chambers were wrapped with an insulating material to prevent the fluctuation of internal air temperature during sampling. For every GHG sampling session during the wheat season, the covers ( $0.5 \mathrm{~m}$ by $0.5 \mathrm{~m}$ by $0.5 \mathrm{~m}$, length by width by height, respectively) were manually placed on the base collars and removed after each measurement session. The same chamber was used for the gas flux measurements during the early growth stages of the maize season. The chambers were then replaced when the maize plants grew beyond $45 \mathrm{~cm}$. New bases were installed at the center of each plot, and smaller chamber covers $(0.5 \mathrm{~m}$ by $0.5 \mathrm{~m}$ by $0.25 \mathrm{~m}$, length by width by height, respectively) consisting of two parts were fixed around the growing maize plant at the center of the chamber base during every sampling session.

The gas samples were taken between 08:00 am-11:00 am, when the temperature was close to the average daily temperature, in order to reduce the effects of diurnal variations in GHG flux patterns [38].

In each field plot, GHG flux measurements were taken every day for the first week following fertilization, every other day during the second week, and twice a week for the rest of the planting season. For the wheat season, the collection of gas samples was shortened due to the coronavirus outbreak in January.

For the GHG flux measurements, five gas samples were taken from the chamber using $60 \mathrm{~mL}$ plastic syringes equipped with three-way stopcocks through a Teflon tube linked to the chamber every 7 min after closing the chamber during each sampling session, similar to the process described in Zhou et al. (2013) [5]. After gas collection, the gas samples were 
transported to the laboratory at the Yanting Agro-ecological Station of Purple Soil. Then the gas concentrations were analyzed within $24 \mathrm{~h}$ using a gas chromatograph (GC) (HP 5890II, Hewlett-Packard, Palo Alto, CA, USA) fitted with an electron capture detector (ECD) for $\mathrm{N}_{2} \mathrm{O}$ analysis and flame ionization detector (FID) for $\mathrm{CH}_{4}$ analysis. The comprehensive GC configurations used to evaluate the gases in this study are as described by Yuesi et al. (2003) [36].

The GHG concentration was converted to mass per volume accounting for auxiliary measurements such as actual air temperature, chamber volume, and ambient pressure per ideal gas law following Pelster et al. (2007) [39] as described in Equation (1).

$$
\mathrm{F}=\frac{\mathrm{b} \times \mathrm{M}_{\mathrm{w}} \times \mathrm{V}_{\mathrm{ch}} \times 60 \times 10^{6}}{\mathrm{~A}_{\mathrm{ch}} \times \mathrm{V}_{\mathrm{m}} \times 10^{9}}
$$

where $\mathrm{F}$ is the flux rate $\left(\mu \mathrm{g} \mathrm{N} \mathrm{m}{ }^{-2} \mathrm{day}^{-1}\right.$ or $\mu \mathrm{g} \mathrm{C} \mathrm{m}^{-2}$ day $\left.^{-1}\right)$ for $\mathrm{N}_{2} \mathrm{O}$ and $\mathrm{CH}_{4}$, respectively, $\mathrm{b}$ (ppm $\left.\min ^{-1}\right)$ is the slope of increase/decrease in concentration, $\mathrm{Mw}$ is the molecular weight of gas $\left(\mathrm{g} \mathrm{mol}^{-1}\right), \mathrm{V}_{\mathrm{Ch}}$ is chamber volume $\left(\mathrm{m}^{3}\right), \mathrm{A}_{\mathrm{ch}}$ is chamber area $\left(\mathrm{m}^{2}\right), \mathrm{V}_{\mathrm{m}}$ is the corrected standard gaseous molar volume $\left(\mathrm{m}^{3} \mathrm{~mol}^{-1}\right)$ given by Equation (2).

$$
\mathrm{V}_{\mathrm{m}}=22.4 \times 10^{-3} \mathrm{~m}^{3} \mathrm{~mol}^{-1} \times \frac{273.15+\text { Temp }}{273.15} \times \frac{\text { air pressure }}{1013}
$$

where Temp $\left({ }^{\circ} \mathrm{C}\right)$ is the chamber air temperature at the time of sampling, and air pressure $(\mathrm{hPa})$ is the atmospheric pressure recorded from the nearby meteorological station.

In this study, we adopted both linear and non-linear models for $\mathrm{N}_{2} \mathrm{O}$ and $\mathrm{CH}_{4}$ flux calculations. The choice of the model was informed by the degree of correlation. When there was a strong correlation $\left(\mathrm{R}^{2}>0.95\right)$ for the nonlinear model, the second-order polynomial model was used; otherwise, the linear model was maintained, with at least three sampling points, similar to the method used in Pelster et al. (2012) [40]. The seasonal cumulative GHG fluxes were then obtained from the fluxes using a linear interpolation process.

\subsection{Soil Analysis and Environmental Variable Measurements}

We obtained soil samples at a depth of $5 \mathrm{~cm}$ and recorded soil temperatures using a manual thermoelectric thermometer (model JM624, Tianjin Jinming Instrument Co. Ltd., Tianjin, China). The moisture content of the soil (at a depth of $5 \mathrm{~cm}$ ) was then determined using the simple drying method as described by Hillel (1971) [41].

The soil available $\mathrm{N}\left(\mathrm{NH}_{4}{ }^{+}\right.$and $\left.\mathrm{NO}_{3}{ }^{-}\right)$was extracted by adding $6 \mathrm{~g}$ of soil samples to $30 \mathrm{~mL} 2 \mathrm{M}$ potassium chloride $(\mathrm{KCl})$ solution, and the extracts were stored at $4{ }^{\circ} \mathrm{C}$ until analysis. The dissolved organic C (DOC) in the soil was extracted by adding $6 \mathrm{~g}$ of each soil sample to $30 \mathrm{~mL}$ of distilled water and shaken for one hour, after which the supernatant was filtered with a $45 \mu \mathrm{m}$ filter. Filtrates for $\mathrm{DOC}, \mathrm{NH}_{4}{ }^{+}$, and $\mathrm{NO}_{3}{ }^{-}$were analyzed using a continuous flow autoanalyzer (model AA3, Bran + Luebbe, Norderstedt, Germany). The $\mathrm{NH}_{4}{ }^{+}$concentrations were measured by heating with salicylate and hypochlorite in an alkaline phosphate buffer. Ethylenediaminetetraacetic acid (EDTA) was used in order to prevent the precipitation of calcium and magnesium. Sodium nitroprusside was added to improve sensitivity. The absorbance of the reaction product was measured at $660 \mathrm{~nm}$ and is directly proportional to the initial ammonia concentration. Soil $\mathrm{NO}_{3}{ }^{-}$concentrations in the filtrates were measured by reduction to $\mathrm{NO}_{2}{ }^{-}$using a copperized cadmium column. The $\mathrm{NO}_{2}{ }^{-}$content was then detected by diazotizing with sulfanilamide followed by coupling with N-(1-naphthyl) ethylenediamine dihydrochloride. The absorbance of the reaction product was then measured at $520 \mathrm{~nm}$. Soil DOC contents were measured by converting all the DOC in the supernatant into $\mathrm{CO}_{2}$ by ultraviolet digestion, which was then measured at $254 \mathrm{~nm}$.

Precipitation and other environmental data were obtained from the meteorological unit of the Yanting Agro-ecological Station of Purple Soil, approximately $50 \mathrm{~m}$ from the 
experimental plots. More information about this is available in the Supplementary Material section.

\subsection{Crop Performance and Global Warming Potential}

In addition to the GHG flux measurements, we also calculated the agronomic output on a dry yield basis from all treatments. At the end of the season, harvesting took place, and four replicates for each treatment were collected to measure crop grain yields after ovendrying the harvested grains at $70{ }^{\circ} \mathrm{C}$ for two days. The combined GWP $\left(\mathrm{kg} \mathrm{CO}_{2}\right.$ eq ha $\left.{ }^{-1}\right)$ associated with the soil $\mathrm{N}_{2} \mathrm{O}$ and $\mathrm{CH}_{4}$ fluxes for each treatment were obtained by adding the partial GWP of each greenhouse gas. The partial GWP $\left(\mathrm{kg} \mathrm{CO}_{2} \mathrm{eq} \mathrm{ha}^{-1}\right)$ for each gas was obtained according to Equation (3) below:

$$
\mathrm{GWP}_{\text {partial }}=\mathrm{F}_{\text {cumm }} \times \mathrm{C}_{\mathrm{f}} \times \mathrm{GWP}_{100}
$$

where $\mathrm{F}_{\text {cumm }}\left(\mathrm{kg} \mathrm{N} \mathrm{ha}^{-1}\right.$ or $\left.\mathrm{kg} \mathrm{C} \mathrm{ha}^{-1}\right)$ is the cumulative $\mathrm{N}_{2} \mathrm{O}$ or $\mathrm{CH}_{4}$ flux, $\mathrm{C}_{\mathrm{f}}$ is the unit stoichiometric conversion factor associated with each gas (44/28 for $\mathrm{N}_{2} \mathrm{O}$ and 16/12 for $\mathrm{CH}_{4}$ ) to convert the weight of nitrogen to the weight of $\mathrm{N}_{2} \mathrm{O}$ and the weight of $\mathrm{C}$ to the weight of $\mathrm{CH}_{4}$, and $\mathrm{GWP}_{100}$ is the 100-year horizon GWP of each greenhouse gas relative to $\mathrm{CO}_{2}$ over a 100-year horizon $\left(\mathrm{N}_{2} \mathrm{O}: 298 ; \mathrm{CH}_{4}\right.$ : 25) [12].

Changes in soil organic C (SOC) stocks following seven years of fertilization with organic manure (from 2003 to 2010) were not statistically significant $(p>0.05)$ [5]. Therefore, changes in soil SOC supplies were not accounted for in our estimates of GWP.

Furthermore, we scaled the combined GWP for $\mathrm{N}_{2} \mathrm{O}$ and $\mathrm{CH}_{4}$ from each fertilization treatment with crop grain yields as suggested by Linquist et al. (2012) [42] to determine how different fertilizer management techniques influence product-related GHG fluxes. That is, soil $\mathrm{N}_{2} \mathrm{O}$ and $\mathrm{CH}_{4}$ fluxes for each fertilized treatment were evaluated on the basis of the ratio of their GWP to grain yield [43].

\subsection{Statistical Analysis}

SPSS 16.0 (SPSS, Inc., Chicago, IL, USA) and Sigma plot 12.5 (Systat Software Inc., Chicago, IL, USA) were used for the statistical analyses and graphical presentation of our data, respectively. The cumulative $\mathrm{N}_{2} \mathrm{O}$ and $\mathrm{CH}_{4}$ emissions, combined GWP, yields and yield-scaled GWP associated with each fertilization treatment were compared using a one-way ANOVA. $\mathrm{N}_{2} \mathrm{O}$ flux data were $\log$-transformed $(\mathrm{y}=\log (\mathrm{x}+1))$ before analysis. The value 1 was added to prevent negative log-transformed values from being produced. Similarly, soil $\mathrm{NH}_{4}{ }^{+}, \mathrm{NO}_{3}{ }^{-}$and DOC concentrations were log-transformed and compared using a one-way ANOVA. The differences between treatments were considered significant at $p<0.05$. The association between weather and soil variables and $\mathrm{N}_{2} \mathrm{O}$ and $\mathrm{CH}_{4}$ fluxes were examined using Pearson's correlation test.

\section{Results}

\subsection{Environmental Variables}

A total precipitation of $792 \mathrm{~mm}$ was recorded during the experimental period (Figure 2a), which was about $93 \%$ of the total precipitation throughout the year, and within the longterm normal values for the average annual precipitation observed in the area. The mean air temperature $\left(17^{\circ} \mathrm{C}\right)$ during the observation period was close to the long-term normal values for the mean annual temperature (Figure $2 \mathrm{a}$ ). During the wheat season, the average air temperature was $12^{\circ} \mathrm{C}$ with a range of $5^{\circ} \mathrm{C}$ to $29^{\circ} \mathrm{C}$, and the average soil temperature at $5 \mathrm{~cm}$ depth was $12{ }^{\circ} \mathrm{C}$ (Figure $2 \mathrm{~b}$ ). Cumulative precipitation was only around $141.1 \mathrm{~mm}$ during the wheat season, and soil moisture ranged from 3\% to 22\% (Figure 2c). However, the cumulative precipitation during the maize season was $651 \mathrm{~mm}$, accounting for close to $82 \%$ of cumulative precipitation observed throughout the experimental period. The average air temperature was $25^{\circ} \mathrm{C}$ with a range of $18{ }^{\circ} \mathrm{C}$ to $30{ }^{\circ} \mathrm{C}$, and the average soil temperature at $5 \mathrm{~cm}$ depth was $25^{\circ} \mathrm{C}$. The soil moisture varied greatly, ranging from $3 \%$ to 
$25 \%$. There were no significant differences in soil temperature or moisture between the treatments during the experimental period (Figure $2 b, c$ ).

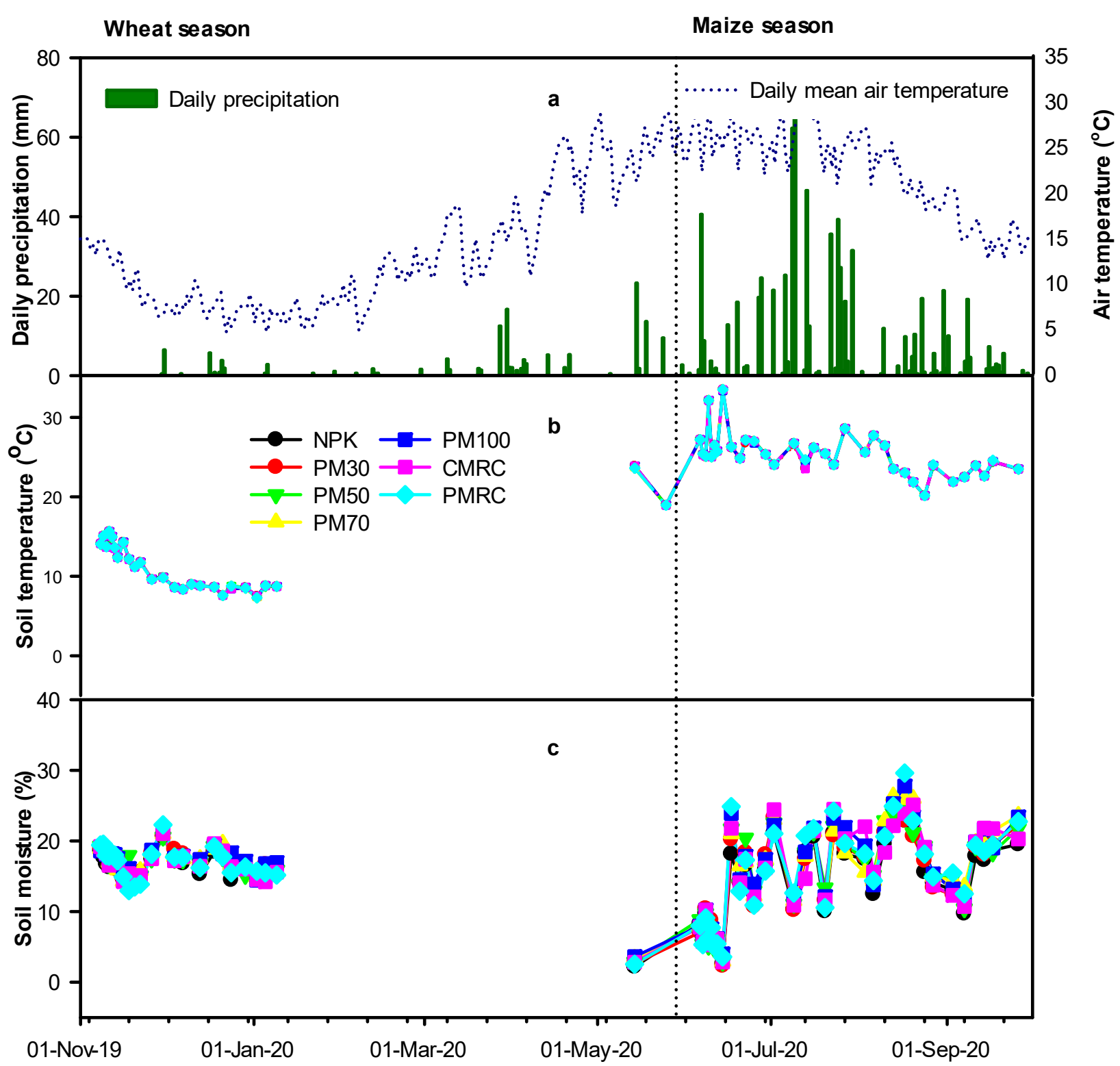

Figure 2. Variations in (a) daily precipitation and air temperature, (b) soil temperature at $5 \mathrm{~cm}$, (c) soil moisture. Error bars have been omitted for clarity. The dashed line indicates the transition between planting seasons, and points indicate average measurements.

\subsection{Effects of Different Fertilization Treatments on Soil Chemical Properties}

The fertilization treatments significantly impacted the concentration of available $\mathrm{N}$ in the soil $(p<0.05)$. $\mathrm{N}$ availability varied across different periods of the growing season, with a high concentration of both $\mathrm{NH}_{4}{ }^{+}$and $\mathrm{NO}_{3}{ }^{-}$being recorded during the first week after fertilization (Figure 3(ai,aii,bi,bii)). However, soil $\mathrm{NH}_{4}{ }^{+}$and $\mathrm{NO}_{3}{ }^{-}$were significantly higher $(p<0.05)$ during the maize season than in the wheat season, with NPK treatments containing relatively higher peaks of both $\mathrm{NH}_{4}{ }^{+}$and $\mathrm{NO}_{3}{ }^{-}$throughout both growing seasons, while PM100 exhibited the consistently low levels of $\mathrm{NH}_{4}{ }^{+}$and $\mathrm{NO}_{3}{ }^{-}$throughout both seasons (Figure 3(ai,aii,bi,bii)). 


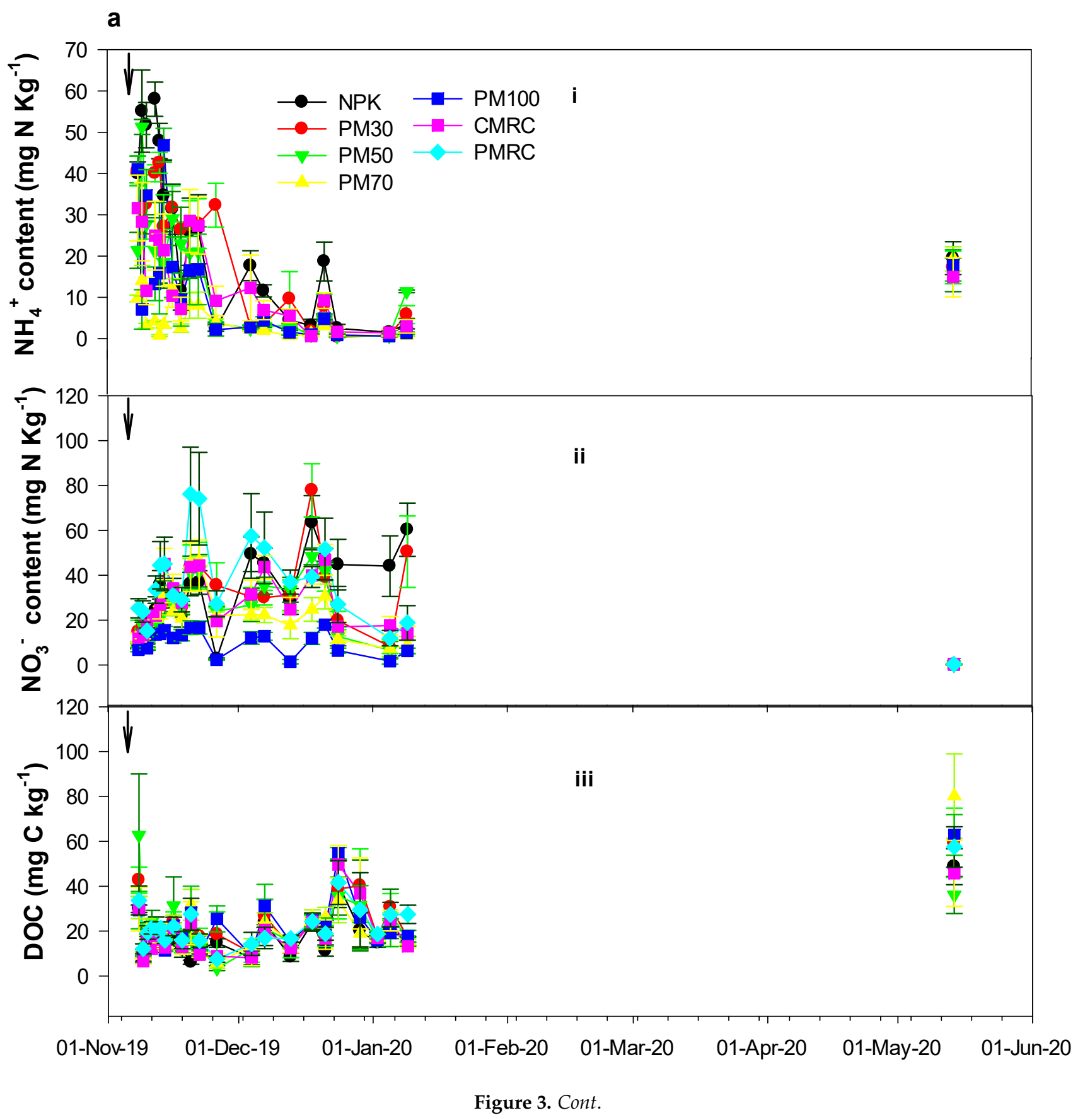


b

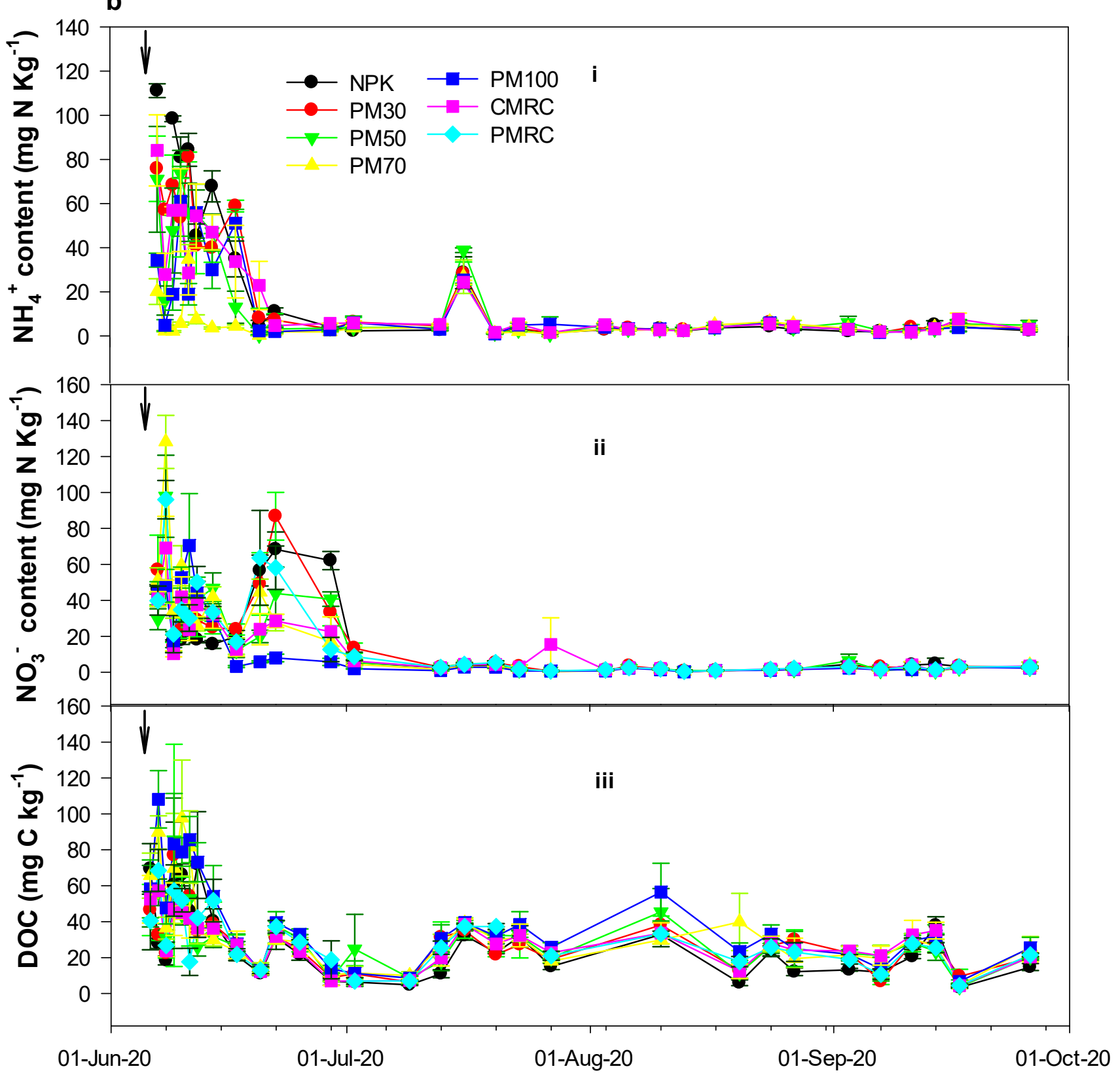

Figure 3. Seasonal variations in (i) soil ammonium $\left(\mathrm{NH}_{4}{ }^{+}\right)$content, (ii) soil nitrate $\left(\mathrm{NO}_{3}{ }^{-}\right)$content and (iii) soil dissolved organic carbon (DOC) content (a) during wheat season's experimental period from November 2019 to May 2020 and (b) during maize season's experimental period from June 2020 to September 2020. The vertical bars indicate the standard errors of different replications $(n=4)$. The vertical arrows indicate the date of planting and fertilization.

The soil DOC contents for the organic amended treatments were significantly higher than the NPK $(p<0.05)$ during the maize season, with the observation of a substantially higher DOC in the PM100 treatments immediately after fertilization (Figure 3(aiii,biii)).

\subsection{Direct $\mathrm{N}_{2} \mathrm{O}$ and $\mathrm{CH}_{4}$ Emissions under Different Fertilization Treatments}

$\mathrm{N}_{2} \mathrm{O}$ fluxes were mostly positive across all treatments (Figure 4(ai,bi)). However, a few negative $\mathrm{N}_{2} \mathrm{O}$ emissions were recorded in the PM70 and PM100 treatments during the winter wheat and in the PM30 treatment during the summer maize season. The $\mathrm{N}_{2} \mathrm{O}$ fluxes ranged between $-34.44 \mu \mathrm{g} \mathrm{N} \mathrm{m}^{-2} \mathrm{hr}^{-1}$ and $52.07 \mu \mathrm{g} \mathrm{N} \mathrm{m}^{-2} \mathrm{hr}^{-1}$ during the observation period of the winter wheat season and $-35.56 \mu \mathrm{g} \mathrm{N} \mathrm{m}^{-2} \mathrm{hr}^{-1}$ to $395.30 \mu \mathrm{g} \mathrm{N} \mathrm{m} \mathrm{N} \mathrm{hr}^{-1}$ dur- 
ing the summer maize season (Figure 4(bi)). Rapid $\mathrm{N}_{2} \mathrm{O}$ emissions occurred immediately after fertilization, which was more pronounced during the summer maize season when most of the $\mathrm{N}_{2} \mathrm{O}$ were emitted within the first two weeks after fertilization. Afterwards, $\mathrm{N}_{2} \mathrm{O}$ emissions mostly remained below $20 \mu \mathrm{g} \mathrm{N} \mathrm{m}{ }^{-2} \mathrm{hr}^{-1}$ throughout the observation period (Figure 4(bi)). As shown in Table 3, the cumulative soil $\mathrm{N}_{2} \mathrm{O}$ emissions for all organic amended soils were significantly lower than the NPK treatment during the maize season $(p<0.01)$. The lowest cumulative $\mathrm{N}_{2} \mathrm{O}$ emission was recorded under the PMRC treatment (Table 3). However, due to high temporal intraseasonal variations in greenhouse gas fluxes, the cumulative emissions for the winter wheat season were not extrapolated.

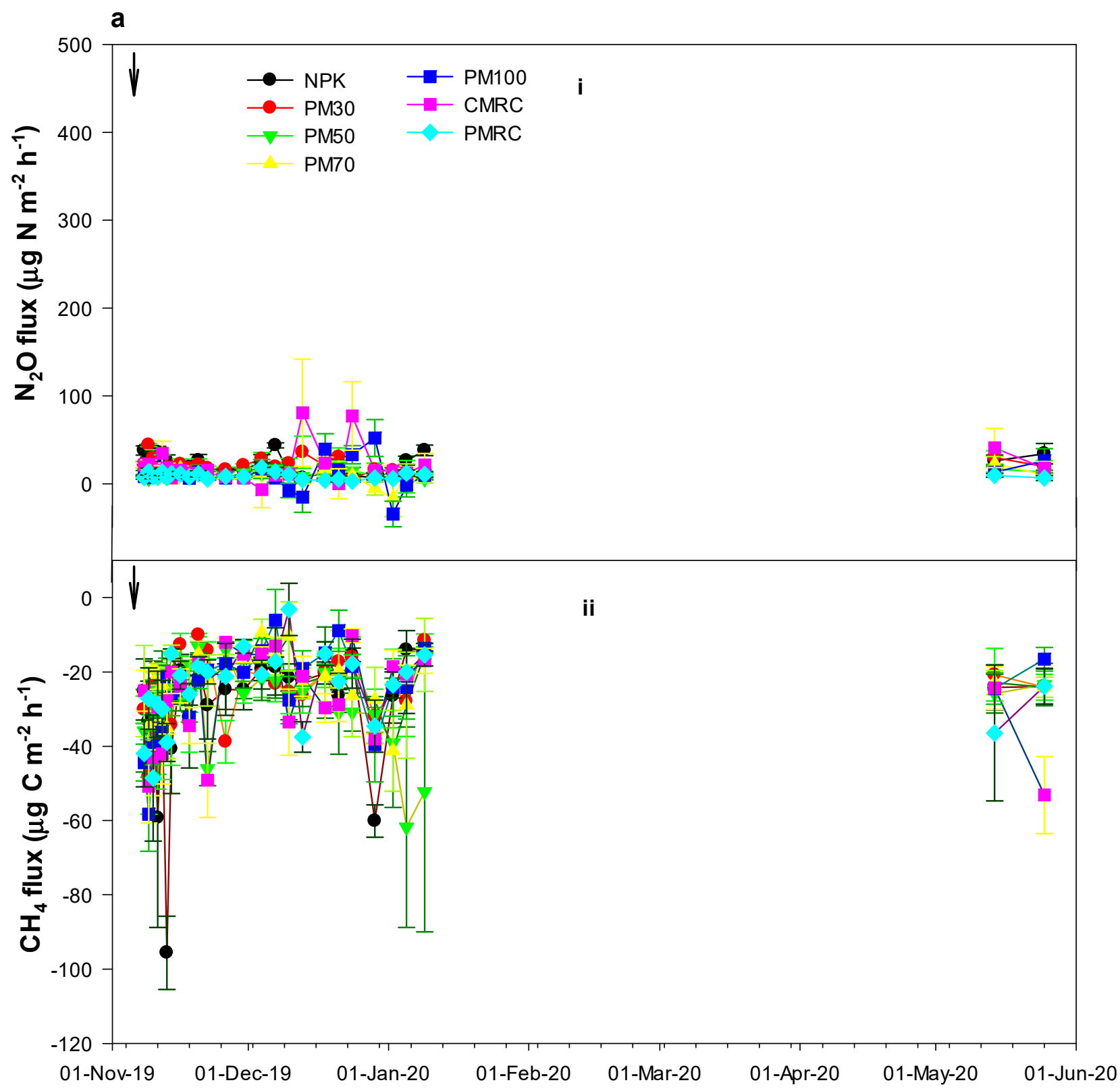

Figure 4. Cont. 
b

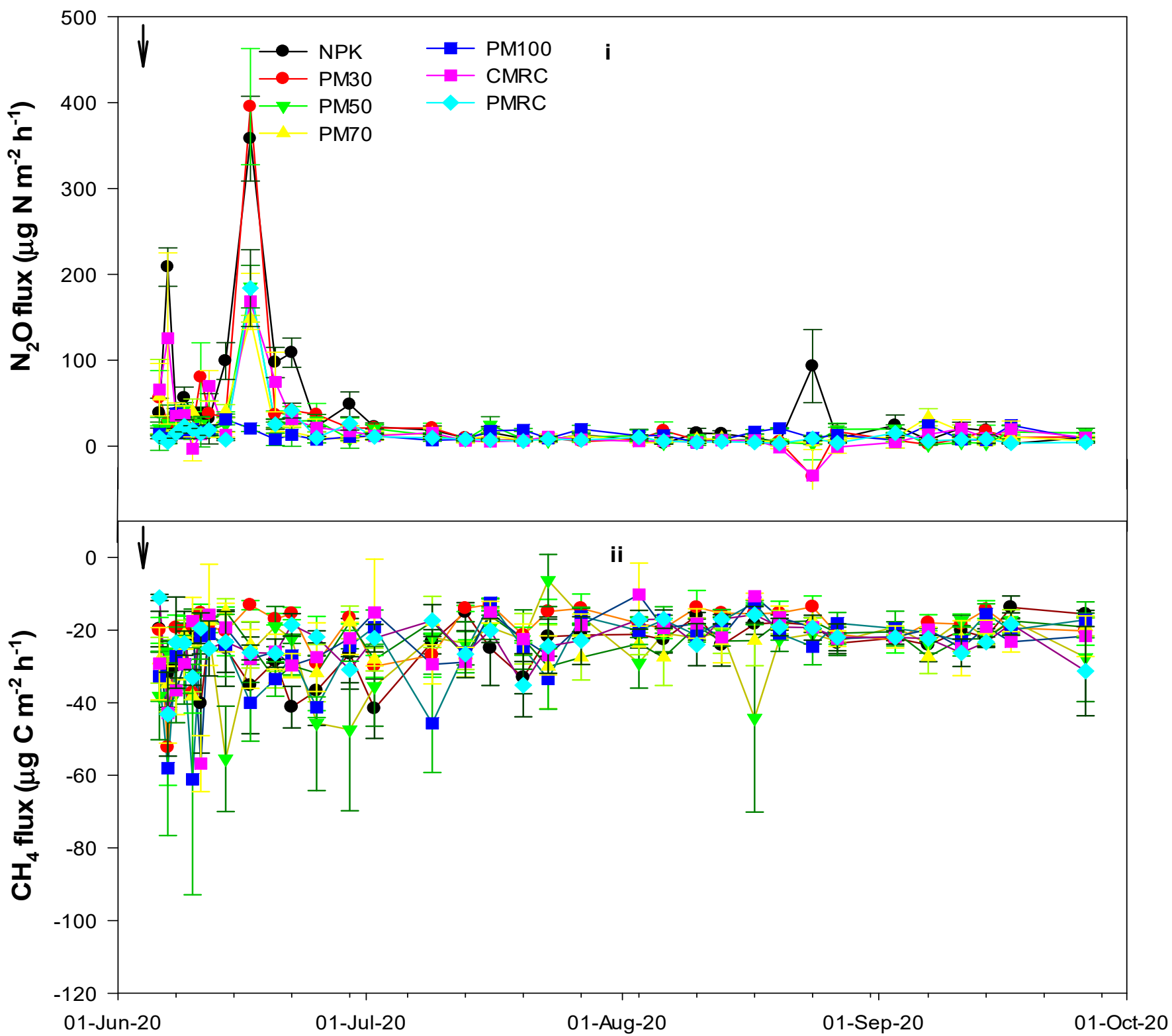

Figure 4. Seasonal variations in (i) soil methane $\left(\mathrm{CH}_{4}\right)$ fluxes and (ii) soil nitrous oxide $\left(\mathrm{N}_{2} \mathrm{O}\right)$ emissions (a) during wheat season's experimental period from November 2019 to May 2020 and (b) during maize season's experimental period from June 2020 to September 2020. The vertical bars indicate the standard errors of different replications $(\mathrm{n}=4)$. The vertical arrows indicate the date of planting and fertilization.

Soil $\mathrm{CH}_{4}$ fluxes were mostly negative across all treatments, ranging between $-96.61 \mu \mathrm{g} \mathrm{C} \mathrm{m}{ }^{-2} \mathrm{hr}^{-1}$ to $-3.17 \mu \mathrm{g} \mathrm{C} \mathrm{m}{ }^{-2} \mathrm{hr}^{-1}$ during the wheat season observation period (Figure 4(aii)) and from $-65.46 \mu \mathrm{g} \mathrm{C} \mathrm{m}^{-2} \mathrm{hr}^{-1}$ to $-6.34 \mu \mathrm{g} \mathrm{C} \mathrm{m} \mathrm{hr}^{-1}$ during the entire summer maize season (Figure 4ii). As shown in Table 3, the cumulative $\mathrm{CH}_{4}$ emissions for the summer maize season were not significantly different across all treatments. 
Table 3. Cumulative soil greenhouse gas (GHG) fluxes, grain yields and combined global warming potential (GWP) as influenced by different fertilization treatments.

\begin{tabular}{|c|c|c|c|c|c|}
\hline Treatment & $\begin{array}{c}\text { Cumulative } \mathrm{N}_{2} \mathrm{O} \\
\text { Emissions } \\
(\mathrm{kg} \mathrm{N} \mathrm{ha}-1)^{*}\end{array}$ & $\begin{array}{c}\text { Cumulative } \mathrm{CH}_{4} \\
\text { Fluxes } \\
\left(\mathrm{kg} \mathrm{C} \mathrm{ha}^{-1)} *\right.\end{array}$ & $\begin{array}{l}\text { Wheat Grain Yield } \\
\left(\mathrm{kg} \mathrm{ha}^{-1}\right)\end{array}$ & $\begin{array}{l}\text { Maize Grain Yield } \\
\left(\mathrm{kg} \mathrm{ha}^{-1}\right)\end{array}$ & $\begin{array}{c}\text { Combined GWP } \\
\left(\mathrm{kg} \mathrm{CO}_{2} \text { eq ha }\right.\end{array}$ \\
\hline NPK & $0.93 \pm 0.1^{\mathrm{a}}$ & $-0.65 \pm 0.1^{\mathrm{a}}$ & $3106.6 \pm 23.1^{a}$ & $7309.8 \pm 46.4^{\mathrm{a}}$ & $412.0 \pm 38.8^{\mathrm{a}}$ \\
\hline РM30 & $0.63 \pm 0.1^{b}$ & $-0.52 \pm 0.0^{\mathrm{a}}$ & $2880.7 \pm 20.6^{a}$ & $6170.8 \pm 38.9^{a b}$ & $289.9 \pm 26.7^{b}$ \\
\hline PM50 & $0.50 \pm 0.1^{b c}$ & $-0.68 \pm 0.1^{\mathrm{a}}$ & $2894.4 \pm 27.1^{a}$ & $5979.0 \pm 53.1^{\mathrm{ab}}$ & $209.6 \pm 29.9 b c$ \\
\hline PM70 & $0.40 \pm 0.0^{c}$ & $-0.62 \pm 0.0^{\mathrm{a}}$ & $2478.2 \pm 13.0^{b}$ & $5866.0 \pm 40.3^{b}$ & $162.7 \pm 17.0^{\mathrm{c}}$ \\
\hline PM100 & $0.43 \pm 0.0^{\mathrm{c}}$ & $-0.65 \pm 0.0^{\mathrm{a}}$ & $1997.4 \pm 11.6^{b}$ & $5384.5 \pm 51.3^{b}$ & $177.8 \pm 16.9^{c}$ \\
\hline CMRC & $0.46 \pm 0.1^{b c}$ & $-0.59 \pm 0.0^{\mathrm{a}}$ & $2706.4 \pm 11.5^{\mathrm{a}}$ & $6700.0 \pm 34.8^{\mathrm{ab}}$ & $197.2 \pm 27.0^{b c}$ \\
\hline PMRC & $0.39 \pm 0.1^{c}$ & $-0.60 \pm 0.0^{\mathrm{a}}$ & $3030.5 \pm 12.2^{\mathrm{a}}$ & $6657.3 \pm 54.0^{a b}$ & $161.2 \pm 28.1^{\mathrm{c}}$ \\
\hline
\end{tabular}

Means with the same letter along the column are not significantly different at $p<0.01$. ${ }^{*}$ The cumulative $\mathrm{N}_{2} \mathrm{O}, \mathrm{CH}_{4}$ and combined GWP reported are based on the measurements in the summer maize season.

\subsection{Crop Yield and Yield-Scaled Global Warming Potential (GWP) under Different Fertilization Treatments}

The grain yields for both seasons for the various treatments were as shown in Table 3. For the winter wheat season, only the yields from the PM70 and PM100 were significantly lower than the conventional NPK treatment $(p<0.01)$. Similar yield patterns were also observed during the summer maize season, with the PM70 and PM100 having significantly lower $(p<0.01)$ maize yields than the conventional NPK fertilizer treatments.

For the maize season, a combined GWP of $412 \mathrm{~kg} \mathrm{CO}_{2}$ eq ha ${ }^{-1}$ was recorded for the NPK treatments, which was significantly higher than that of the organic-amended treatments $(p<0.01$, Table 3$)$. Among the treatments in this study, the PMRC treatment showed the lowest GWP of $162 \mathrm{~kg} \mathrm{CO}_{2}$ eq ha ${ }^{-1}$ (Table 3). Due to similar $\mathrm{CH}_{4}$ fluxes among all the fertilization treatments, the combined GWP followed a similar pattern as the cumulative $\mathrm{N}_{2} \mathrm{O}$ emission, as shown in Table 3. As for the yield-scaled GWP, except for the PM30 treatment, the yield-scaled GWP for the organically amended soils were significantly lower than the NPK treatment ( $p<0.01$, Figure 5).

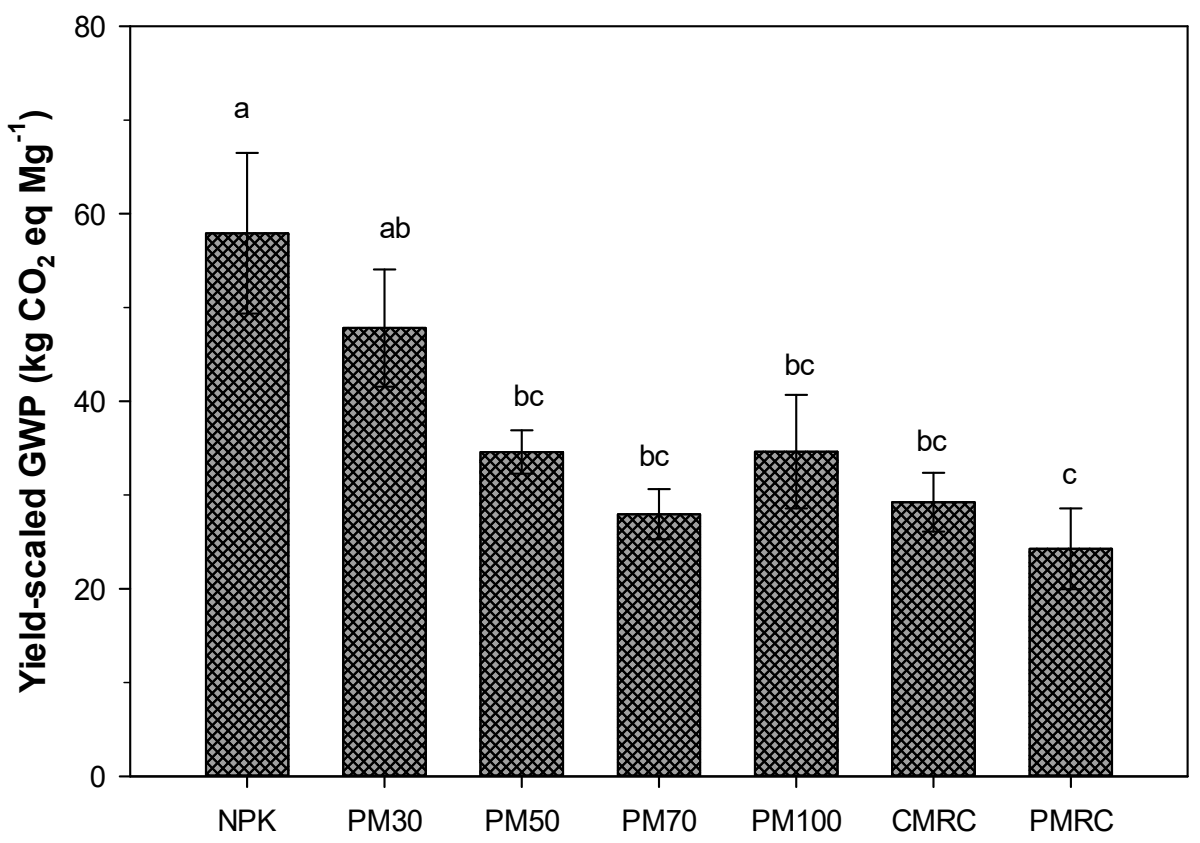

Figure 5. Yield-scaled global warming potential associated with each fertilization treatment. The vertical bars indicate the standard errors of different replications $(n=4)$. Different lower case letters indicate a statistical difference $(p<0.01)$ among the fertilized treatments. 


\subsection{Correlations between Greenhouse Gas and Soil Properties}

The $\mathrm{N}_{2} \mathrm{O}$ fluxes had significant positive correlations with soil $\mathrm{NO}_{3}{ }^{-}$concentration under all the treatments and were also significantly positively correlated with $\mathrm{NH}_{4}{ }^{+}$concentration under NPK, PM30, PM50, PM70 and PMRC treatments (Table 4). Additionally, $\mathrm{N}_{2} \mathrm{O}$ fluxes were significantly positively correlated with available $\mathrm{N}$ under all treatments. Moreover, $\mathrm{N}_{2} \mathrm{O}$ fluxes also had significant positive correlations with soil temperature under PM30, PM50, CMRC treatments and were also significantly positively correlated with DOC under NPK and PM30 treatments. However, $\mathrm{N}_{2} \mathrm{O}$ fluxes had significant negative correlations with the soil moisture under NPK, PM30, PM70 and PM100 treatments (Table 4).

Table 4. Correlations of greenhouse gas and soil properties under different fertilization treatments.

\begin{tabular}{|c|c|c|c|c|c|c|c|}
\hline & Treatments & $\begin{array}{c}\text { Soil } \\
\text { Temperature }\end{array}$ & $\mathrm{NH}_{4}{ }^{+}$ & $\mathrm{NO}_{3}^{-}$ & $\begin{array}{c}\text { Available } \mathrm{N} \\
\left(\mathrm{NH}_{4}{ }^{+}+\mathrm{NO}_{3}{ }^{-}\right)\end{array}$ & DOC & Soil Moisture \\
\hline \multirow{7}{*}{$\mathrm{N}_{2} \mathrm{O}$} & NPK & 0.248 & $0.576^{* *}$ & $0.677^{* *}$ & $0.634^{* *}$ & $0.430 *$ & $-0.419 *$ \\
\hline & РМ30 & $0.441 *$ & $0.716^{* *}$ & 0.733 ** & $0.422 *$ & 0.383 * & $-0.393 *$ \\
\hline & PM50 & $0.494^{* *}$ & $0.502^{* *}$ & $0.605^{* *}$ & $0.491^{* *}$ & 0.270 & -0.266 \\
\hline & PM70 & 0.414 * & $0.525^{* *}$ & $0.586^{* *}$ & $0.516^{* *}$ & 0.221 & $-0.401 *$ \\
\hline & PM100 & 0.333 & 0.205 & $0.515^{* *}$ & $0.501^{* *}$ & 0.307 & $-0.352 *$ \\
\hline & CMRC & $0.367 *$ & 0.277 & $0.459 *$ & $0.420 *$ & 0.060 & -0.241 \\
\hline & PMRC & 0.219 & $0.389 *$ & $0.482^{* *}$ & 0.406 * & 0.066 & -0.209 \\
\hline \multirow{7}{*}{$\mathrm{CH}_{4}$} & NPK & -0.147 & -0.222 & $-0.446^{*}$ & -0.361 & -0.073 & 0.214 \\
\hline & РМ30 & -0.083 & -0.349 & $-0.383 *$ & $-0.405^{*}$ & -0.023 & $0.427 *$ \\
\hline & PM50 & $-0.364^{*}$ & -0.241 & $-0.413^{*}$ & $-0.366^{*}$ & -0.066 & 0.241 \\
\hline & PM70 & -0.035 & -0.042 & -0.288 & -0.197 & -0.291 & 0.120 \\
\hline & PM100 & -0.195 & -0.091 & $-0.421 *$ & $-0.444 *$ & -0.271 & $0.439 * *$ \\
\hline & CMRC & -0.185 & -0.192 & $-0.478^{* *}$ & -0.386 * & -0.238 & $0.488^{* *}$ \\
\hline & PMRC & 0.320 & -0.361 & $-0.497^{* *}$ & -0.224 & 0.004 & $0.454^{* *}$ \\
\hline
\end{tabular}

** Correlation is significant at 0.01 level (2-tailed). * Correlation is significant at 0.05 level (2-tailed).

Similarly, as shown in Table 4, $\mathrm{CH}_{4}$ fluxes showed significant positive correlations with soil moisture under PM30, PM100, CMRC and PMRC treatments, and significant negative correlations with soil $\mathrm{NO}_{3}{ }^{-}$concentration were observed under NPK, PM30, PM50, PM100, CMRC and PMRC treatments.

\section{Discussion}

\subsection{Factors Controlling $\mathrm{N}_{2} \mathrm{O}$ and $\mathrm{CH}_{4}$ Emissions}

According to our study, $\mathrm{NO}_{3}{ }^{-}$concentrations were strongly significantly and positively correlated with $\mathrm{N}_{2} \mathrm{O}$ emissions $(p<0.01)$, while $\mathrm{NH}_{4}{ }^{+}$concentrations showed partial correlations with $\mathrm{N}_{2} \mathrm{O}$ emissions in some treatments. This observation implies that an increase in soil available $\mathrm{N}$ content resulted in higher $\mathrm{N}_{2} \mathrm{O}$ emissions, which is consistent with observations made by Liu et al. (2020) and Miller et al. (2008) [18,44]. Moreover, the positive correlation of soil available $\mathrm{N}$ with $\mathrm{N}_{2} \mathrm{O}$ emissions $(p<0.05)$ was also reported by other researchers who concluded that soil available $\mathrm{N}$ are substrates for microbial nitrification and denitrification, which can result in the production of $\mathrm{N}_{2} \mathrm{O}$ [40,45-47]. This finding could also explain the reason why the highest $\mathrm{N}_{2} \mathrm{O}$ pulses for all treatments occurred within the first two weeks following the fertilizers' application during the maize season, when more than $50 \%$ of the $\mathrm{N}_{2} \mathrm{O}$ emissions occurred; since there was high soil available $\mathrm{N}$ content during the first few weeks following fertilizer application.

The period of high pulses of $\mathrm{N}_{2} \mathrm{O}$ also coincided with the early event of high precipitation, as shown in Figures 2a and 3b. Interestingly, although apparent negative correlations were found between soil moisture content and $\mathrm{N}_{2} \mathrm{O}$ emissions, signifying that soil moisture content could have a negative influence on soil $\mathrm{N}_{2} \mathrm{O}$ emissions in this study, high $\mathrm{N}_{2} \mathrm{O}$ emissions for the treatments were observed during periods of high precipitation, at the start of the maize season when the amount of soil available $\mathrm{N}$ contents were high. A number of studies have observed significant positive correlations between soil moisture 
content and $\mathrm{N}_{2} \mathrm{O}$ emissions, implying that soil moisture content could stimulate microbial activities, thereby resulting in increased $\mathrm{N}_{2} \mathrm{O}$ production $[3,48,49]$. As demonstrated by Bateman et al. (2005) and Kusa et al. (2002), precipitation could enhance $\mathrm{N}_{2} \mathrm{O}$ emission when the concentration of available $\mathrm{N}$ is very high due to the increase in substrate diffusivity and the stimulation of microbial activity with increased soil moisture content $[48,49]$ thereby resulting in increased denitrification rates [50,51]. The negative correlation observed, which was apparent after the first episode of high precipitation on 17 June 2020 where increases in soil moisture content were found to result in lower $\mathrm{N}_{2} \mathrm{O}$ emissions, could be attributed to the stimulation of complete denitrification by high soil moisture in $\mathrm{N}$-limited systems with high amounts of labile $C$ [52]. As observed in Figures $3 \mathrm{~b}$ and $4 \mathrm{~b}$, by shifting towards an $\mathrm{N}$-limited system after high pulses of $\mathrm{N}_{2} \mathrm{O}$ emissions and significant decreases in available $\mathrm{N}$ in the system (possibly lost through leaching), the high quantities of labile $\mathrm{C}$ relative to $\mathrm{NO}_{3}{ }^{-}$might have promoted complete denitrification $[53,54]$, thereby resulting in decreased $\mathrm{N}_{2} \mathrm{O}$ emissions. Similar results were also observed by Ball et al. (2004), Meijide et al. (2007) and Meijide et al. (2009), who noted that high quantities of labile $\mathrm{C}$ and relatively lower amounts of available $\mathrm{N}$ could suppress $\mathrm{N}_{2} \mathrm{O}$ emissions by lowering the $\mathrm{N}_{2} \mathrm{O}: \mathrm{N}_{2}$ ratio during the denitrification process [19-21].

Although temperature only showed partial significant correlations with both $\mathrm{N}_{2} \mathrm{O}$ and $\mathrm{CH}_{4}$ fluxes, it may have had an enormous influence on $\mathrm{N}_{2} \mathrm{O}$ and $\mathrm{CH}_{4}$ fluxes between both wheat and maize seasons. According to our study, the average soil temperature during the wheat season was $12^{\circ} \mathrm{C}$, while the average soil temperature during the maize season was $25^{\circ} \mathrm{C}$. These large temperature changes could probably account for the enormous differences in $\mathrm{N}_{2} \mathrm{O}$ peaks in the first two weeks of fertilization in both wheat and maize seasons, with most treatments showing three- to six-fold differences in $\mathrm{N}_{2} \mathrm{O}$ flux pulse intensity. Additionally, the highest peak flux recorded for most of the treatments occurred on the date of our soil temperature maxima $\left(\sim 33.5^{\circ} \mathrm{C}\right)$, indicating that high temperatures during the maize season could stimulate microbial processes of nitrification and denitrification, resulting in high amounts of soil available $\mathrm{N}$, and therefore producing abundant substrates for soil $\mathrm{N}_{2} \mathrm{O}$ emissions [55].

Our study indicates significant positive correlations between $\mathrm{CH}_{4}$ emissions and soil moisture content $(p<0.05)$ for most of the organic amended treatments under study. This agrees with reports from previous studies indicating that soil moisture content could exert a strong control on fertilizer-amended soils [56-58]. In their study, Dasselaar et al. (1998) observed that soil moisture accounted for up to $73 \%$ of the variability in $\mathrm{CH}_{4}$ from two aerobic sandy soils. As observed in our study, the apparent positive correlation between soil moisture content and $\mathrm{CH}_{4}$ emissions signifies the inhibition of $\mathrm{CH}_{4}$ uptake by increases in soil moisture content. This phenomenon could be due to gas transport limitations which occurs as a consequence of increased moisture content, consequently resulting in lower $\mathrm{CH}_{4}$ oxidation [25,59]. Moreover, as observed in our study, soil $\mathrm{NO}_{3}{ }^{-}$content was also found to have a significant negative correlation with $\mathrm{CH}_{4}$ emissions $(p<0.05)$, indicating that soil $\mathrm{NO}_{3}{ }^{-}$was positively correlated with $\mathrm{CH}_{4}$ uptakes. This agrees with the observations of Castro et al. (1995), who noted that soil $\mathrm{NO}_{3}{ }^{-}$content could be a strong controller of $\mathrm{CH}_{4}$ consumption at low levels of soil moisture [59]. Additionally, fertilization can also affect $\mathrm{CH}_{4}$ oxidation by influencing the activities of methanotrophic microbes since fertilization can result in the increase in the concentration of $\mathrm{NO}_{3}{ }^{-}$in soils, and $\mathrm{NO}_{3}{ }^{-}$can facilitate cell growth of the methanotrophic microbes [25].

\subsection{Effects of Different Fertilization Treatments on $\mathrm{N}_{2} \mathrm{O}$ and $\mathrm{CH}_{4}$ Fluxes}

Studies involving the use of organic amendments on agricultural soils have reported conflicting findings regarding their influence on $\mathrm{N}_{2} \mathrm{O}$ emissions in relation to $\mathrm{N}$ fertilizer application. While some studies have reported that organic amendments have a stimulating effect on $\mathrm{N}_{2} \mathrm{O}$ emissions compared to synthetic $\mathrm{N}$ fertilizers [18,60], others have reported a suppressing effect $[61,62]$. Our study showed significantly lower soil $\mathrm{N}_{2} \mathrm{O}$ emissions in both wheat and maize seasons during the first few weeks following fertilization and significantly 
lower cumulative $\mathrm{N}_{2} \mathrm{O}$ emissions during the maize season from plots amended with organic amendments compared to the synthetic $\mathrm{N}$ treatment $(p<0.05)$. The findings were consistent with the results reported by Nyamadzawo et al. (2017) and Mukumbuta et al. (2017), who also noted that partial substitution of organic amendments resulted in lower $\mathrm{N}_{2} \mathrm{O}$ in organic amended soils when compared to full synthetic $\mathrm{N}$ fertilizer treatments $[63,64]$. Nyamadzawo et al. (2017) observed between $15 \%$ to $37 \% \mathrm{~N}_{2} \mathrm{O}$ emission reduction in soils amended with different proportions of cattle manure in a Hapilic Lixisol maize system [63]. However, our results were contrary to the observations of Jin et al. (2010), who observed an increased level of $\mathrm{N}_{2} \mathrm{O}$ emissions in a Mollic Andosol reed canary grassland amended with beef cattle manure [65]. This discrepancy could be attributed to the difference in the physicochemical nature of the organic amendments used in their study and our study. It has been reported that the $\mathrm{N}_{2} \mathrm{O}$ stimulating or suppressing effects of an organic amendment could be influenced by its $\mathrm{C} / \mathrm{N}$ ratio [66]. The authors reported a threshold value of approximately 8.6, a $\mathrm{C} / \mathrm{N}$ ratio below which organic amendments tended to cause a stimulating effect on $\mathrm{N}_{2} \mathrm{O}$ emissions [66]. As observed in Table 2, the $\mathrm{C} / \mathrm{N}$ ratio of the amendments used was higher than this threshold, indicating that the $\mathrm{N}_{2} \mathrm{O}$ emissions can be suppressed in the organic amended soils studied here. Moreover, another possible explanation for the relatively lower $\mathrm{N}_{2} \mathrm{O}$ fluxes in organic-amended treatments could be due to the slow release of mineralized $\mathrm{N}$ in organic amended soils [67], which results in the lower substrates available for $\mathrm{N}_{2} \mathrm{O}$ production. This assumption can also be supported by the distribution patterns of available $\mathrm{N}$ among treatments in Figure 3.

Previous studies have reported that the use of organic amendments such as manures, composts, and crop residues could affect the $\mathrm{CH}_{4}$ uptake capacity of soils [68]. In our study, however, such a relationship was not found. Similarly, we did not observe any significant difference in the $\mathrm{CH}_{4}$ uptake capacities of soils with different organic amendment types, which is in agreement with the previous results observed in the area [5]. Also, we did not observe any significant impact of the differential increase in manure $\mathrm{N}$ ratio on soil's $\mathrm{CH}_{4}$ uptake capacity. This phenomenon could be explained by the comparable soil moisture content across all treatments in this study since soil moisture has been shown to be an important controller of $\mathrm{CH}_{4}$ consumption based on its significant correlation with $\mathrm{CH}_{4}$ emissions, which probably accounts for the similar $\mathrm{CH}_{4}$ flux values in the soils under study.

Additionally, as seen in our study, based on the variations in the $\mathrm{N}_{2} \mathrm{O}$ and $\mathrm{CH}_{4}$ emission as well as the crop yields among treatments, combining inorganic $\mathrm{N}$ with lower or equal proportions of organic manure $\mathrm{N}$ or compost can be used as a mitigation option for reducing $\mathrm{N}_{2} \mathrm{O}$ emissions while retaining similar crop yields. However, if manure is the main or only source of $\mathrm{N}$, the yield loss may be up to $36 \%$. A similar observation was observed by Nyamadzawo et al. (2017) in Chinese and Zimbabwean cereal systems [63].

\subsection{Impact of Different Fertilization Treatments on Yield-Scaled GWP}

Analyzing the global warming potential associated with fertilization treatments in agricultural systems provides interesting information for estimating the environmental impacts of intensive agricultural production. A few studies have directly reported the combined GWP for $\mathrm{N}_{2} \mathrm{O}$ and $\mathrm{CH}_{4}$ emissions in grain production systems $[5,42,69]$. These studies report a range of values varying over approximately one order of magnitude. In this study, the combined GWP across all the treatments ranged from $161.2 \mathrm{~kg} \mathrm{CO}_{2} \mathrm{eq} \mathrm{ha}^{-1}$ for PMRC to $412.0 \mathrm{~kg} \mathrm{CO}_{2} \mathrm{eq} \mathrm{ha}^{-1}$ for the NPK treatment, which was within the range of GWP reported by Linquist et al. (2012) from a meta-analysis of 62 studies and 328 global observations [42], and similar to the values obtained during the maize season within the area, and from previous studies in wheat systems reported in the area $[5,68,70]$. The combined GWP for $\mathrm{N}_{2} \mathrm{O}$ and $\mathrm{CH}_{4}$ observed during the maize season were significantly lower for all the organically amended treatments than the NPK treatment, as seen in Table 3. These observations were similar to the findings of Liu et al. (2020), López-Fernández et al. (2007) and Musafiri et al. (2020) [44,62,71]. Due to similar $\mathrm{CH}_{4}$ emissions recorded across 
all fertilization treatments, the variation in GWP in this study was mainly accounted for by the differences in cumulative $\mathrm{N}_{2} \mathrm{O}$ emissions for the various treatments.

In addition, several reports have recommended using yield-scaled GWP as an important metric to finding the most suitable fertilization strategy that would lower the environmental impacts of fertilizer use without resulting in yield penalties [5,42,72]. For a sustainable fertilizer management option, a pragmatic approach to finding an environmentally friendly amendment involves taking grain yields into account in order to juxtapose both the environmental and economic impacts of different fertilizer management strategies. In our study, except for the PM30 treatment, the yield-scaled GWP of the organic-amended treatments were significantly lower than the NPK treatment $(p<0.05)$, demonstrating the suitability of organic fertilizer-synthetic $\mathrm{N}$ combination as a suitable alternative for the NPK-only treatment. The lower yield-scaled GWP observed in the organic-amended treatments studied here were attributed to the lower cumulative $\mathrm{N}_{2} \mathrm{O}$ fluxes and similar yields with respect to the NPK treatment.

Our study focused on the influence of the application of organic amendments on $\mathrm{N}_{2} \mathrm{O}$ and $\mathrm{CH}_{4}$ fluxes and their impact on crop yields in a Sichuan basin wheat-maize system. The application of organic amendments could significantly impact SOC pools in agricultural soils and could, therefore, influence their $\mathrm{CO}_{2}$ emissions [73-77]. However, we did not integrate soil organic carbon changes and associated $\mathrm{CO}_{2}$ emissions in our estimates of GWP. Therefore, long-term observation of SOC changes and their associated $\mathrm{CO}_{2}, \mathrm{CH}_{4}$ and $\mathrm{N}_{2} \mathrm{O}$ emissions are required to fully characterize the net GWP in organic-amended Sichuan basin wheat-maize system.

\section{Conclusions}

This paper explores the effects of organic amendment types and increasing differential manure $\mathrm{N}$ ratios on greenhouse gas emissions, GWP and yield-scaled GWP in a wheat-maize system in southwest China as well as the drivers controlling greenhouse gas emissions. In this study, the conventional NPK fertilizer had the highest $\mathrm{N}_{2} \mathrm{O}$ emission and consequently the highest GWP and yield-scaled GWP among the fertilization treatments, while a balanced $\mathrm{N}$ fertilization (synthetic $\mathrm{N}+$ low or equal proportions of pig manure/compost) could maintain relatively high grain yield and reduce the risk of high $\mathrm{N}_{2} \mathrm{O}$ emissions while not significantly affecting $\mathrm{CH}_{4}$ fluxes in wheat-maize systems. Therefore, up to $50 \%$ of the synthetic $\mathrm{N}$ fertilizer can be substituted by pig manure or compost in this area. As for the driver controlling greenhouse gas emissions, we found that available $\mathrm{N}$ exerts strong control on $\mathrm{N}_{2} \mathrm{O}$ and $\mathrm{CH}_{4}$ emissions. Additionally, among the organic-amended treatments, our study revealed that the PMRC treatment had the lowest yield-scaled GWP, owing to its ability to significantly reduce $\mathrm{N}_{2} \mathrm{O}$ emissions while maintaining high crop yields, thereby highlighting it as the most suitable of the organic fertilization treatments under our study, which could reduce the GWP associated with fertilizer use in wheat-maize systems.

Supplementary Materials: The following are available online at https: / www.mdpi.com/article / $10.3390 /$ atmos12091104/s1.

Author Contributions: Conceptualization, D.G.O., K.W. and B.Z.; methodology, D.G.O. and K.W.; software, D.G.O., L.H. and H.B.; validation, K.W., B.Z.; formal analysis, D.G.O., L.H.; investigation, D.G.O.; resources, B.Z.; data curation, D.G.O.; writing—original draft preparation, D.G.O.; writingreview and editing, K.W., A.M., L.A.G.; visualization, A.M. and H.B.; supervision, B.Z.; project administration, K.W. and B.Z.; funding acquisition, K.W. and B.Z. All authors have read and agreed to the published version of the manuscript.

Funding: This research was funded by the National Natural Science Foundation of China, grant number U20A20107; the Youth Innovation Promotion Association, CAS, grant number 2021374; the Sichuan provincial department of agriculture and rural affairs, China; the Mianyang Municipal Science and Technology Bureau, China; CAS the 'Belt and Road' Master Fellowship Program and CAS President's International Fellowship Initiative (PIFI). 
Institutional Review Board Statement: Not applicable.

Informed Consent Statement: Not applicable.

Data Availability Statement: The data presented in this study are available on request from the corresponding authors.

Acknowledgments: We are thankful to all members of staff at the Yanting Agro-ecological Station of Purple Soil for their contribution during the field experiments.

Conflicts of Interest: The authors declare no conflict of interest.

\section{References}

1. Food and Agriculture Organization of the United Nations (FAO). Organic Agriculture and Climate Change Mitigation-A Report of the Round Table on Organic Agriculture and Climate Change; FAO: Rome, Italy, 2011.

2. Smith, P.; Martino, D.; Cai, Z.; Gwary, D.; Janzen, H.; Kumar, P.; McCarl, B.; Ogle, S.; O’Mara, F.; Rice, C.; et al. Agriculture. In Climate Change 2007: Mitigation. Contribution of Working Group III to the Fourth Assessment Report of the Intergovernmental Panel on Climate Change; Cambridge University Press: Cambridge, UK; New York, NY, USA, 2007.

3. Liu, H.; Li, J.; Li, X.; Zheng, Y.; Feng, S.; Jiang, G. Mitigating greenhouse gas emissions through replacement of chemical fertilizer with organic manure in a temperate farmland. Sci. Bull. 2015, 60, 598-606. [CrossRef]

4. Nayak, D.R.; Saetnan, E.; Cheng, K.; Wang, W.; Koslowski, F.; Cheng, Y.-F.; Zhu, W.Y.; Wang, J.-K.; Liu, J.-X.; Moran, D.; et al. Management opportunities to mitigate greenhouse gas emissions from Chinese agriculture. Agric. Ecosyst. Environ. 2015, 209, 108-124. [CrossRef]

5. Zhou, M.; Zhu, B.; Brüggemann, N.; Bergmann, J.; Wang, Y.; Butterbach-Bahl, $\mathrm{K}_{2} \mathrm{~N}_{2} \mathrm{O}$ and $\mathrm{CH}_{4}$ Emissions, and $\mathrm{NO}_{3}-\mathrm{Leaching}$ on a Crop-Yield Basis from a Subtropical Rain-fed Wheat-Maize Rotation in Response to Different Types of Nitrogen Fertilizer. Ecosystems 2013, 17, 286-301. [CrossRef]

6. Xiu, Y.; Cheng, Y. The Comprehensive Utilization of Crops Straw Stalk and the Rural Circulation Economy. J. Agric. Mech. Res. 2006, 10, 31-33. (In Chinese)

7. Bai, Z.; Ma, L.; Jin, S.; Ma, W.; Velthof, G.L.; Oenema, O.; Liu, L.; Chadwick, D.; Zhang, F. Nitrogen, Phosphorus, and Potassium Flows through the Manure Management Chain in China. Environ. Sci. Technol. 2016, 50, 13409-13418. [CrossRef]

8. Chadwick, D.; Wei, J.; Yan'An, T.; Guanghui, Y.; Qirong, S.; Qing, C. Improving manure nutrient management towards sustainable agricultural intensification in China. Agric. Ecosyst. Environ. 2015, 209, 34-46. [CrossRef]

9. Zhou, M.; Zhu, B.; Wang, X.; Wang, Y. Long-term field measurements of annual methane and nitrous oxide emissions from a Chinese subtropical wheat-rice rotation system. Soil Biol. Biochem. 2017, 115, 21-34. [CrossRef]

10. Shan, J.; Yan, X. Effects of crop residue returning on nitrous oxide emissions in agricultural soils. Atmos. Environ. 2013, 71, 170-175. [CrossRef]

11. Yao, Z.; Zheng, X.; Xie, B.; Mei, B.; Wang, R.; Butterbach-Bahl, K.; Zhu, J.; Yin, R. Tillage and crop residue management significantly affects N-trace gas emissions during the non-rice season of a subtropical rice-wheat rotation. Soil Biol. Biochem. 2009, 41, 2131-2140. [CrossRef]

12. Intergovernmental Panel Climate Change. Fourth Assessment Report: Climate Change 2007: The AR4 Synthesis Report; IPCC: Geneva, Switzerland, 2007.

13. Firestone, M.K.; Davidson, E.A. Microbiological basis of $\mathrm{NO}$ and $\mathrm{N}_{2} \mathrm{O}$ production and consumption in soil. In Exchange of Trace Gases Between Terrestrial Ecosystems and the Atmosphere, 1st ed.; Andreae, M., Schimel, D., Eds.; John Wiley and Sons Ltd Chichester: New York, NY, USA, 1990; Volume 47, pp. 7-21.

14. Malhi, S.S.; Lemke, R. Tillage, Crop Residue and N Fertilizer Effects on Crop Yield, Nutrient Uptake, Soil Quality and Nitrous Oxide Gas Emissions in a Second 4-Yr Rotation Cycle. Soil Tillage Res. 2007, 96, 269-283. [CrossRef]

15. Rowlings, D.W.; Grace, P.R.; Kiese, R.; Weier, K.L. Environmental factors controlling temporal and spatial variability in the soil-atmosphere exchange of $\mathrm{CO}_{2}, \mathrm{CH}_{4}$ and $\mathrm{N}_{2} \mathrm{O}$ from an Australian subtropical rainforest. Glob. Chang. Biol. 2012, 18, 726-738. [CrossRef]

16. Vallejo, A.; Skiba, U.M.; Garcia, A.V.; Arce, A.; Lopez-Fernandez, S.; Sanchez-Martin, L. Nitrogen oxides emission from soils bearing a potato crop as influenced by fertilization with treated pig slurries and composts. Soil Biol. Biochem. 2006, 38, 2782-2793. [CrossRef]

17. Jones, S.; Rees, R.; Skiba, U.; Ball, B. Influence of organic and mineral $\mathrm{N}$ fertiliser on $\mathrm{N}_{2} \mathrm{O}$ fluxes from a temperate grassland. Agric. Ecosyst. Environ. 2007, 121, 74-83. [CrossRef]

18. Miller, M.; Zebarth, B.; Dandie, C.; Burton, D.; Goyer, C.; Trevors, J. Crop residue influence on denitrification, N2O emissions and denitrifier community abundance in soil. Soil Biol. Biochem. 2008, 40, 2553-2562. [CrossRef]

19. Meijide, A.; Díez, J.A.; Sanchez-Martin, L.; López-Fernández, S.; Vallejo, A. Nitrogen oxide emissions from an irrigated maize crop amended with treated pig slurries and composts in a Mediterranean climate. Agric. Ecosyst. Environ. 2007, 121, 383-394. [CrossRef]

20. Meijide, A.; García-Torres, L.; Arce, A.; Vallejo, A. Nitrogen oxide emissions affected by organic fertilization in a non-irrigated Mediterranean barley field. Agric. Ecosyst. Environ. 2009, 132, 106-115. [CrossRef] 
21. Ball, B.; McTaggart, I.; Scott, A. Mitigation of greenhouse gas emissions from soil under silage production by use of organic manures or slow-release fertilizer. Soil Use Manag. 2006, 20, 287-295. [CrossRef]

22. Snyder, C.; Bruulsema, T.; Jensen, T.; Fixen, P. Review of greenhouse gas emissions from crop production systems and fertilizer management effects. Agric. Ecosyst. Environ. 2009, 133, 247-266. [CrossRef]

23. Aronson, E.L.; Helliker, B.R. Methane flux in non-wetland soils in response to nitrogen addition: A meta-analysis. Ecology 2010, 91, 3242-3251. [CrossRef] [PubMed]

24. Hütsch, B.W. Methane oxidation in non-flooded soils as affected by crop production-Invited paper. Eur. J. Agron. 2001, 14, 237-260. [CrossRef]

25. Bodelier, P.L.; Laanbroek, H. Nitrogen as a regulatory factor of methane oxidation in soils and sediments. FEMS Microbiol. Ecol. 2004, 47, 265-277. [CrossRef]

26. Raza, S.T.; Zhu, B.; Tang, J.L.; Ali, Z.; Anjum, R.; Bah, H.; Iqbal, H.; Ren, X.; Ahmad, R. Nutrients Recovery during Vermicomposting of Cow Dung, Pig Manure, and Biochar for Agricultural Sustainability with Gases Emissions. Appl. Sci. 2020, 10, 8956. [CrossRef]

27. Zhang, J.; Zeng, G.; Chen, Y.; Yu, M.; Yu, Z.; Li, H.; Yu, Y.; Huang, H. Effects of physico-chemical parameters on the bacterial and fungal communities during agricultural waste composting. Bioresour. Technol. 2011, 102, 2950-2956. [CrossRef]

28. Magrí, A. Research Trends on Nutrient Management From Digestates Assessed Using a Bibliometric Approach. Front. Sustain. Food Syst. 2018, 2. [CrossRef]

29. Walsh, J.J.; Jones, D.L.; Edwards-Jones, G.; Williams, A.P. Replacing inorganic fertilizer with anaerobic digestate may maintain agricultural productivity at less environmental cost. J. Plant Nutr. Soil Sci. 2012, 175, 840-845. [CrossRef]

30. Cui, Y.-F.; Meng, J.; Wang, Q.-X.; Zhang, W.-M.; Cheng, X.-Y.; Chen, W.-F. Effects of straw and biochar addition on soil nitrogen, carbon, and super rice yield in cold waterlogged paddy soils of North China. J. Integr. Agric. 2017, 16, 1064-1074. [CrossRef]

31. Bah, H.; Zhou, M.; Ren, X.; Hu, L.; Dong, Z.; Zhu, B. Effects of organic amendment applications on nitrogen and phosphorus losses from sloping cropland in the upper Yangtze River. Agric. Ecosyst. Environ. 2020, 302, 107086. [CrossRef]

32. Zhang, B.; Zhou, M.; Lin, H.; Ntacyabukura, T.; Wang, Y.; Zhu, B. Effects of different long-term crop straw management practices on ammonia volatilization from subtropical calcareous agricultural soil. Atmos. Ocean. Sci. Lett. 2020, 13, 232-239. [CrossRef]

33. Zhu, B.; Wang, T.; Kuang, F.; Luo, Z.; Tang, J.; Xu, T. Measurements of Nitrate Leaching from a Hillslope Cropland in the Central Sichuan Basin, China. Soil Sci. Soc. Am. J. 2009, 73, 1419-1426. [CrossRef]

34. Omirou, M.; Anastopoulos, I.; Fasoula, D.A.; Ioannides, I.M. The effect of chemical and organic N inputs on N2O emission from rain-fed crops in Eastern Mediterranean. J. Environ. Manag. 2020, 270, 110755. [CrossRef]

35. Wang, J.; Zhu, B.; Zhang, J.; Müller, C.; Cai, Z. Mechanisms of soil N dynamics following long-term application of organic fertilizers to subtropical rain-fed purple soil in China. Soil Biol. Biochem. 2015, 91, 222-231. [CrossRef]

36. Yuesi, W.; Yinghong, W. Quick measurement of $\mathrm{CH}_{4}, \mathrm{CO}_{2}$ and $\mathrm{N}_{2} \mathrm{O}$ emissions from a short-plant ecosystem. Adv. Atmos. Sci. 2003, 20, 842-844. [CrossRef]

37. Zheng, X.; Xie, B.; Liu, C.; Zhou, Z.; Yao, Z.; Wang, Y.; Wang, Y.; Yang, L.; Zhu, J.; Huang, Y.; et al. Quantifying net ecosystem carbon dioxide exchange of a short-plant cropland with intermittent chamber measurements. Glob. Biogeochem. Cycles 2008, 22. [CrossRef]

38. Parkin, T.B.; Venterea, R.T. USDA-ARS GRACEnet Project Protocols, Chapter 3. Chamber-Based Trace Gas Flux Measure-ments. In Sampling Protocols; USDA-ARS: Beltsville, MD, USA, 2010; pp. 1-39.

39. Pelster, D.; Rufino, M.; Rosenstock, T.; Mango, J.; Saiz, G.; Diaz-Pines, E.; Baldi, G.; Butterbach-Bahl, K. Smallholder farms in eastern African tropical highlands have low soil greenhouse gas fluxes. Biogeosciences 2017, 14, 187-202. [CrossRef]

40. Pelster, D.; Chantigny, M.H.; Rochette, P.; Angers, D.A.; Rieux, C.; Vanasse, A. Nitrous Oxide Emissions Respond Differently to Mineral and Organic Nitrogen Sources in Contrasting Soil Types. J. Environ. Qual. 2012, 41, 427-435. [CrossRef]

41. Hillel, D. Soil and Water. In Physical Principles and Processes; Academic Press: Cambridge, MA, USA, 1971.

42. Linquist, B.; van Groenigen, K.J.; Adviento-Borbe, M.A.; Pittelkow, C.; Van Kessel, C. An agronomic assessment of greenhouse gas emissions from major cereal crops. Glob. Chang. Biol. 2011, 18, 194-209. [CrossRef]

43. Grassini, P.; Cassman, K.G. High-yield maize with large net energy yield and small global warming intensity. Proc. Natl. Acad. Sci. USA 2012, 109, 1074-1079. [CrossRef] [PubMed]

44. Liu, D.; Sun, H.; Liao, X.; Luo, J.; Lindsey, S.; Yuan, J.; He, T.; Zaman, M.; Ding, W. $\mathrm{N}_{2} \mathrm{O}$ and NO Emissions as Affected by the Continuous Combined Application of Organic and Mineral N Fertilizer to a Soil on the North China Plain. Agronomy 2020, 10, 1965. [CrossRef]

45. Liu, L.; Estiarte, M.; Peñuelas, J. Soil moisture as the key factor of atmospheric $\mathrm{CH}_{4}$ uptake in forest soils under environmental change. Geoderma 2019, 355, 113920. [CrossRef]

46. Shimizu, M.; Hatano, R.; Arita, T.; Kouda, Y.; Mori, A.; Matsuura, S.; Niimi, M.; Jin, T.; Desyatkin, A.R.; Kawamura, O.; et al. The effect of fertilizer and manure application on $\mathrm{CH}_{4}$ and $\mathrm{N}_{2} \mathrm{O}$ emissions from managed grasslands in Japan. Soil Sci. Plant Nutr. 2013, 59, 69-86. [CrossRef]

47. Hu, X.-K.; Su, F.; Ju, X.-T.; Gao, B.; Oenema, O.; Christie, P.; Huang, B.-X.; Jiang, R.-F.; Zhang, F.-S. Greenhouse gas emissions from a wheat-maize double cropping system with different nitrogen fertilization regimes. Environ. Pollut. 2013, 176, 198-207. [CrossRef] [PubMed] 
48. Bateman, E.J.; Baggs, E.M. Contributions of nitrification and denitrification to $\mathrm{N}_{2} \mathrm{O}$ emissions from soils at different water-filled pore space. Biol. Fertil. Soils 2005, 41, 379-388. [CrossRef]

49. Kusa, K.; Sawamoto, T.; Hatano, R. Nitrous oxide emissions for 6 years from a gray lowland soil cultivated with onions in Hokkaido, Japan. Nutr. Cycl. Agroecosyst. 2002, 63, 239-247. [CrossRef]

50. Saggar, S.; Jha, N.; Deslippe, J.; Bolan, N.; Luo, J.; Giltrap, D.; Kim, D.-G.; Zaman, M.; Tillman, R. Denitrification and $\mathrm{N}_{2} \mathrm{O}$ :N 2 production in temperate grasslands: Processes, measurements, modelling and mitigating negative impacts. Sci. Total. Environ. 2012, 465, 173-195. [CrossRef]

51. Li, M.; Shimizu, M.; Hatano, R. Evaluation of $\mathrm{N}_{2} \mathrm{O}$ and $\mathrm{CO}_{2}$ hot moments in managed grassland and cornfield, southern Hokkaido, Japan. Catena 2015, 133, 1-13. [CrossRef]

52. Millar, N.; Robertson, G.; Grace, P.R.; Gehl, R.J.; Hoben, J.P. Nitrogen fertilizer management for nitrous oxide $\left(\mathrm{N}_{2} \mathrm{O}\right)$ mitigation in intensive corn (Maize) production: An emissions reduction protocol for US Midwest agriculture. Mitig. Adapt. Strat. Glob. Chang. 2010, 15, 185-204. [CrossRef]

53. Iqbal, J.; Parkin, T.B.; Helmers, M.J.; Zhou, X.; Castellano, M. Denitrification and Nitrous Oxide Emissions in Annual Croplands, Perennial Grass Buffers, and Restored Perennial Grasslands. Soil Sci. Soc. Am. J. 2014, 79, 239-250. [CrossRef]

54. Burchill, W.; Li, D.; Lanigan, G.J.; Williams, M.; Humphreys, J. Interannual variation in nitrous oxide emissions from perennial ryegrass/white clover grassland used for dairy production. Glob. Chang. Biol. 2014, 20, 3137-3146. [CrossRef] [PubMed]

55. Butterbach-Bahl, K.; Baggs, L.; Dannenmann, M.; Kiese, R.; Zechmeister-Boltenstern, S. Nitrous oxide emissions from soils: How well do we understand the processes and their controls? Philos. Trans. R. Soc. B Biol. Sci. 2013, 368, 20130122. [CrossRef]

56. Dasselaar, A.V.D.P.-V.; Van Beusichem, M.L.; Oenema, O. Effects of soil moisture content and temperature on methane uptake by grasslands on sandy soils. Plant Soil 1998, 204, 213-222. [CrossRef]

57. Wu, X.; Wang, F.; Li, T.; Fu, B.; Lv, Y.; Liu, G. Nitrogen additions increase N2O emissions but reduce soil respiration and CH4 uptake during freeze-thaw cycles in an alpine meadow. Geoderma 2020, 363, 114157. [CrossRef]

58. Wang, Y.; Cheng, S.; Fang, H.; Yu, G.; Xu, M.; Dang, X.; Li, L.; Wang, L. Simulated Nitrogen Deposition Reduces CH4 Uptake and Increases N2O Emission from a Subtropical Plantation Forest Soil in Southern China. PLoS ONE 2014, 9, e93571. [CrossRef]

59. Castro, M.S.; Steudler, P.A.; Melillo, J.M.; Aber, J.D.; Bowden, R.D. Factors controlling atmospheric methane consumption by temperate forest soils. Glob. Biogeochem. Cycles 1995, 9, 1-10. [CrossRef]

60. Zhou, M.; Zhu, B.; Wang, S.; Zhu, X.; Vereecken, H.; Brüggemann, N. Stimulation of N2O emission by manure application to agricultural soils may largely offset carbon benefits: A global meta-analysis. Glob. Chang. Biol. 2017, 23, 4068-4083. [CrossRef]

61. Ren, F.; Zhang, X.; Liu, J.; Sun, N.; Wu, L.; Li, Z.; Xu, M. A synthetic analysis of greenhouse gas emissions from manure amended agricultural soils in China. Sci. Rep. 2017, 7, 1-13. [CrossRef]

62. Musafiri, C.M.; Macharia, J.M.; Kiboi, M.N.; Ng'Etich, O.K.; Shisanya, C.A.; Okeyo, J.M.; Mugendi, D.N.; Okwuosa, E.A.; Ngetich, F.K. Soil greenhouse gas fluxes from maize cropping system under different soil fertility management technologies in Kenya. Agric. Ecosyst. Environ. 2020, 301, 107064. [CrossRef]

63. Nyamadzawo, G.; Shi, Y.; Chirinda, N.; Olesen, J.E.; Mapanda, F.; Wuta, M.; Wu, W.; Meng, F.; Oelofse, M.; de Neergaard, A.; et al. Combining organic and inorganic nitrogen fertilisation reduces $\mathrm{N}_{2} \mathrm{O}$ emissions from cereal crops: A comparative analysis of China and Zimbabwe. Mitig. Adapt. Strat. Glob. Chang. 2014, 22, 233-245. [CrossRef]

64. Mukumbuta, I.; Shimizu, M.; Hatano, R. Mitigating Global Warming Potential and Greenhouse Gas Intensities by Applying Composted Manure in Cornfield: A 3-Year Field Study in an Andosol Soil. Agriculture 2017, 7, 13. [CrossRef]

65. Jin, T.; Shimizu, M.; Marutani, S.; Desyatkin, A.R.; Iizuka, N.; Hata, H.; Hatano, R. Effect of chemical fertilizer and manure application on $\mathrm{N}_{2} \mathrm{O}$ emission from reed canary grassland in Hokkaido, Japan. Soil Sci. Plant Nutr. 2010, 56, 53-65. [CrossRef]

66. He, T.; Yuan, J.; Luo, J.; Wang, W.; Fan, J.; Liu, D.; Ding, W. Organic fertilizers have divergent effects on soil $\mathrm{N}_{2} \mathrm{O}$ emissions. Biol. Fertil. Soils 2019, 55, 685-699. [CrossRef]

67. Masunga, R.H.; Uzokwe, V.N.; Mlay, P.D.; Odeh, I.; Singh, A.; Buchan, D.; De Neve, S. Nitrogen mineralization dynamics of different valuable organic amendments commonly used in agriculture. Appl. Soil Ecol. 2016, 101, 185-193. [CrossRef]

68. Lin, S.; Zhang, S.; Shen, G.; Shaaban, M.; Ju, W.; Cui, Y.; Duan, C.; Fang, L. Effects of inorganic and organic fertilizers on $\mathrm{CO}_{2}$ and $\mathrm{CH}_{4}$ fluxes from tea plantation soil. Elem. Sci. Anth. 2021, 9. [CrossRef]

69. Bah, H.; Ren, X.; Wang, Y.; Tang, J.; Zhu, B. Characterizing Greenhouse Gas Emissions and Global Warming Potential of Wheat-Maize Cropping Systems in Response to Organic Amendments in Eutric Regosols, China. Atmosphere 2020, $11,614$. [CrossRef]

70. Zhou, M.; Zhu, B.; Butterbach-Bahl, K.; Zheng, X.; Wang, T.; Wang, Y. Nitrous oxide emissions and nitrate leaching from a rain-fed wheat-maize rotation in the Sichuan Basin, China. Plant Soil 2012, 362, 149-159. [CrossRef]

71. López-Fernández, S.; Díez, J.A.; Hernáiz, P.; Arce, A.; Garcia, A.V.; Vallejo, A. Effects of fertiliser type and the presence or absence of plants on nitrous oxide emissions from irrigated soils. Nutr. Cycl. Agroecosyst. 2007, 78, 279-289. [CrossRef]

72. Van Groenigen, J.W.; Velthof, G.; Oenema, O.; van Groenigen, K.J.; Van Kessel, C. Towards an agronomic assessment of $\mathrm{N}_{2} \mathrm{O}$ emissions: A case study for arable crops. Eur. J. Soil Sci. 2010, 61, 903-913. [CrossRef]

73. Rahman, M. Carbon Dioxide Emission from Soil. Agric. Res. 2013, 2, 132-139. [CrossRef]

74. Shrestha, B.M.; Chang, S.X.; Bork, E.W.; Carlyle, C.N. Enrichment Planting and Soil Amendments Enhance Carbon Sequestration and Reduce Greenhouse Gas Emissions in Agroforestry Systems: A Review. Forests 2018, 9, 369. [CrossRef] 
75. Kitamura, R.; Sugiyama, C.; Yasuda, K.; Nagatake, A.; Yuan, Y.; Du, J.; Yamaki, N.; Taira, K.; Kawai, M.; Hatano, R. Effects of Three Types of Organic Fertilizers on Greenhouse Gas Emissions in a Grassland on Andosol in Southern Hokkaido, Japan. Front. Sustain. Food Syst. 2021, 5, 100. [CrossRef]

76. Zhang, T.; Liu, H.; Luo, J.; Wang, H.; Zhai, L.; Geng, Y.; Li, J.; Lei, Q.; Bashir, M.A.; Wu, S.; et al. Long-term manure application increased greenhouse gas emissions but had no effect on ammonia volatilization in a Northern China upland field. Sci. Total. Environ. 2018, 633, 230-239. [CrossRef] [PubMed]

77. Adair, E.C.; Barbieri, L.; Schiavone, K.; Darby, H.M. Manure Application Decisions Impact Nitrous Oxide and Carbon Dioxide Emissions during Non-Growing Season Thaws. Soil Sci. Soc. Am. J. 2019, 83, 163-172. [CrossRef] 